MARMARA COĞRAFYA DERGISI SAYI: 31, OCAK - 2015, S.415-446

ISTANBUL - ISSN:1303-2429 E-ISSN 2147-7825 copyright $@ 2015$

http://www.marmaracografya.com

\title{
KONYA İLİNDE GÜNCEL OBRUK OLUŞUMLARI ${ }^{1}$ Current Sinkholes Formations in Konya Province
}

\author{
Doç. Dr. Tahsin TAPUR \\ Necmettin Erbakan Üniversitesi, Ahmet Keleşoğlu Ĕ̈itim Fakültesi, \\ Coğrafya Eğitimi ABD, ttapur@hotmail.com \\ Yrd. Doç. Dr. Recep BOZYİĞİT \\ Necmettin Erbakan Üniversitesi, Ahmet Keleşoğlu Eğitim Fakültesi, \\ Coğrafya Ĕ̌itimi ABD, rbozyigit@konya.edu.tr
}

\section{ÖZET}

Konya İli ve çevresi sahip olduğu jeolojik yapı, yeraltı suları ve tektonizmanın etkisiyle eskiden beri obruk oluşumlarına sahne olmuştur. Obruklar, oluşum dönemlerine göre eski ve güncel oluşumlu obruklar olarak sinıflandırabilir. Son dönemde Konya Havzası'ndaki obruk sayısında artış kaydedilmiştir. Obruk sayısının artmasında; sahada kurak ve yarı kurak iklim koşullarının yaşanmasının yanı sıra beşeri faktörlerin etkileri de görülmektedir.

Obruk oluşumlarl geçmişten beri insan faaliyetlerini olumlu ve olumsuz yönde etkilemektedir. Son yıllarda obruk oluşumlarının artması, özellikle yaylacılık faaliyetlerini ve tarım yapılan alanları olumsuz yönde etkilemeye başlamıştır. Bu nedenle obruk oluşan alanların jeolojik-jeofizik etütlere dayalı risk haritası oluşturulmall, obruk oluşum sahaları sürekli izlenmeli, yöre halkına yönelik periyodik eğitim seminerleri verilmelidir.

Bu çalışmada güncel obrukların; oluşumu, morfometrik özellikleri ve dağılımına yer verilmiştir.

Anahtar Kelimeler: Karapınar, güncel obruk, obruk tehdidi, karstlaşma

\section{ABSRACT}

The geological structure in Konya and surroundings, due to the impact of underground waters and tectonics movements, has witnessed many sinkholes formations. According to their time of formations sinkholes are categorized as old and new formations. There has been an increase in sinkholes formations within Konya base. In the increase in sinkholes information, arid to sub arid climate conditions as well as human factors have an impact.

\footnotetext{
${ }^{1}$ Bu çalışma, Necmettin Erbakan Üniversitesi Bilimsel Araştırma Projeleri (BAP) Fonu tarafından 131210002 proje numarası ile desteklenmiştir.
} 
Sinkholes formations have been affecting human activities both positively and negatively throughout history. The fact that sinkholes formations have increased in recent years has begun to have a negative effect on agricultural activities and transhumance. That's why, geological-geophysical surveying based risk maps should be created in the areas where sinkholes have formed, tracked and local people informed regularly.

The present study is about recent pothole formations, their morphometric features, and distributions.

Keywords: Karapinar, current sinkholes, sinkholes threat, karstification

\section{GİRIŞ}

Konya İli obruklarına; Karapınar, Çumra, Karatay, Akören başta olmak üzere Ereğli ve Kadınhanı ilçelerinde rastlanmaktadır (Şekil 1).

Konya Havzası'nın alt yapısını metamorfik ve kristalen kütleler ile Kretase yaşı ofiolitik seriler teşkil eder. Bu temel birimlerin üzerinde altta Miosen, üstte Pliosen yaşlı birimler ile en üstte Kuaterner yaşlı örtü formasyonları yer alır. Yatay yapılı bu birimler; altta taban konglomeras1 ile başlar, üste doğru marn, kalker, kil, kum, çakıl taşları ve yer yer de jipslerden oluşur (Selçuk Biricik, 1992). Bölgede yer alan bu litolojik yap1 obruk oluşumuna son derece elverişlidir. Güneyde Toros Dağları'ndan başlayarak kuzeye doğru Konya Kapalı Havzası ve oradan da Tuz Gölü Havzası'na doğru bir yeraltı suyu akımı mevcuttur. Bu akıma bağlı olarak eriyebilen/çözünebilen kayaçların bulunduğu alanlarda da yer yer karstik boşluklar oluşmaktadır. Bu karstik boşluklar, zamanla genişler ve üzerindeki toprak katmanlarını taşıyamayacak bir seviyeye gelir. Yüzeydeki toprak katmanlarının çökmesi sonucunda da obruklar oluşur (Üstün vd., 2007: 54).

Konya Havzası sahip olduğu jeolojik yap1, yeralt1 suları, tektonizmanın etkisiyle obruk oluşumlarına sahne olmuştur. Ancak günümüzde obruk sayısının artmasında sahada kurak ve yarıkurak iklim koşullarının yaşanmasının yanı sıra beşeri faktörlerin de etkileri görülmektedir. Bu obruklar, oluşum dönemlerine göre eski oluşumlu ve güncel obruklar şeklinde sınıflandırılabilir². Konya İli’nde eski ve güncel

\footnotetext{
${ }^{2}$ Obruklar farklı kriterler dikkate alınarak sınıflandırılabilirler. Bu çalışmada obrukların oluşum zamanları dikkate alınarak eski ve güncel obruklar şeklinde sınıflandırılmıştır. Güncel obruklar, son yıllarda (1972-2014) oluşan obrukları kapsamaktadır.
} 
104 obruk tespit edilmiştir. Obruklardan 61 tanesi eski, 43 tanesi ise yeni oluşumludur (Şekil 2). Bu çalışmada yeni oluşumlu; güncel obruklara yer verilecektir.

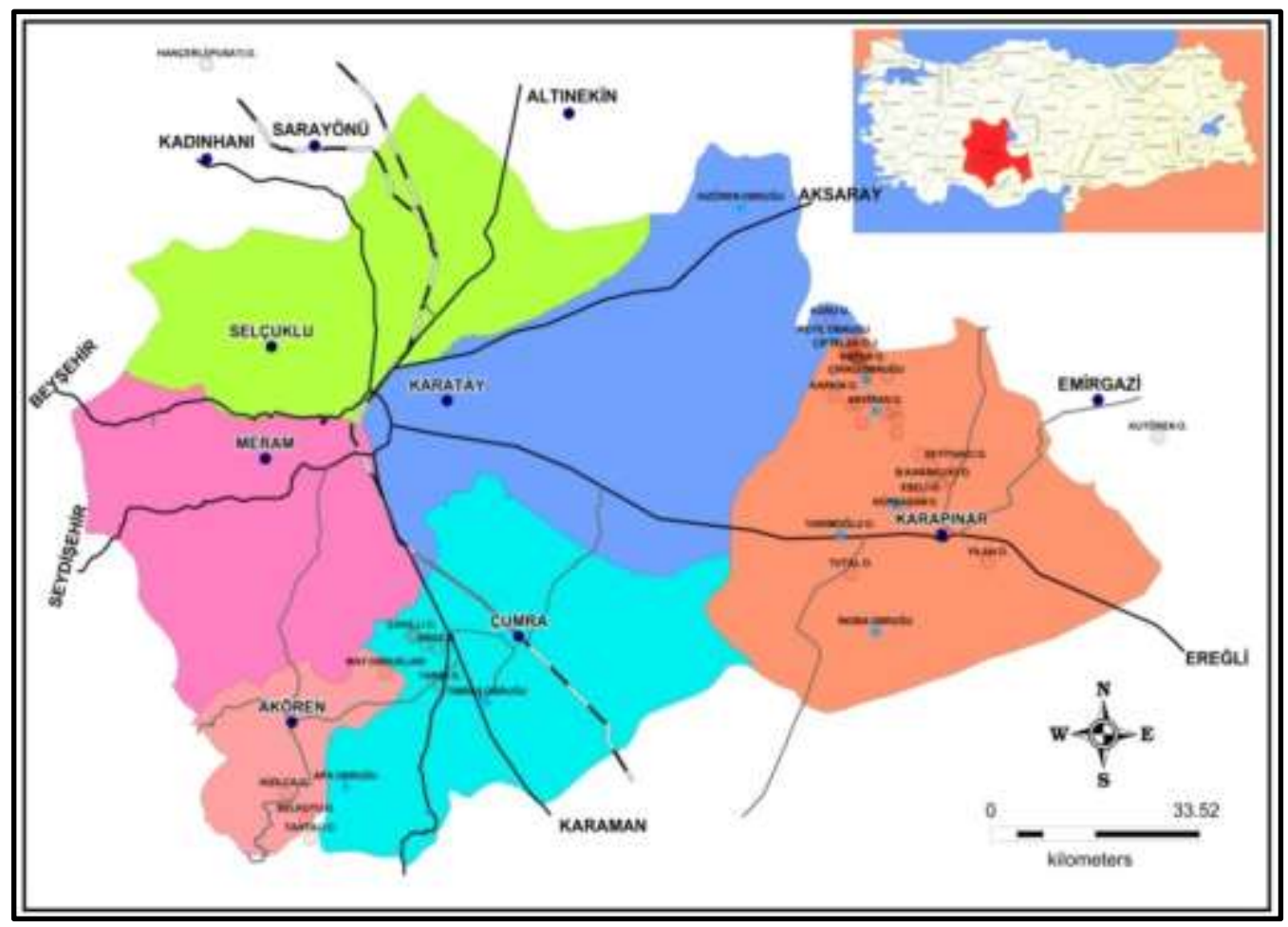

Şekil 1: Konya İli Obruklarının Lokasyon Haritası

Bölgede obruklarla ilgili olarak; Lahn (1940), Güldalı ve Şaroğlu (1983), Erol (1990), Selçuk Biricik (1992), Çörekçioğlu (1994), Canik (1997), Bayart vd. (2008), Bozyiğit ve Tapur (2009), Ertek (2009), Törk vd. (2010), Göçmez (2011) gibi araştırıcılar çalışmalar yapmışlardır. 


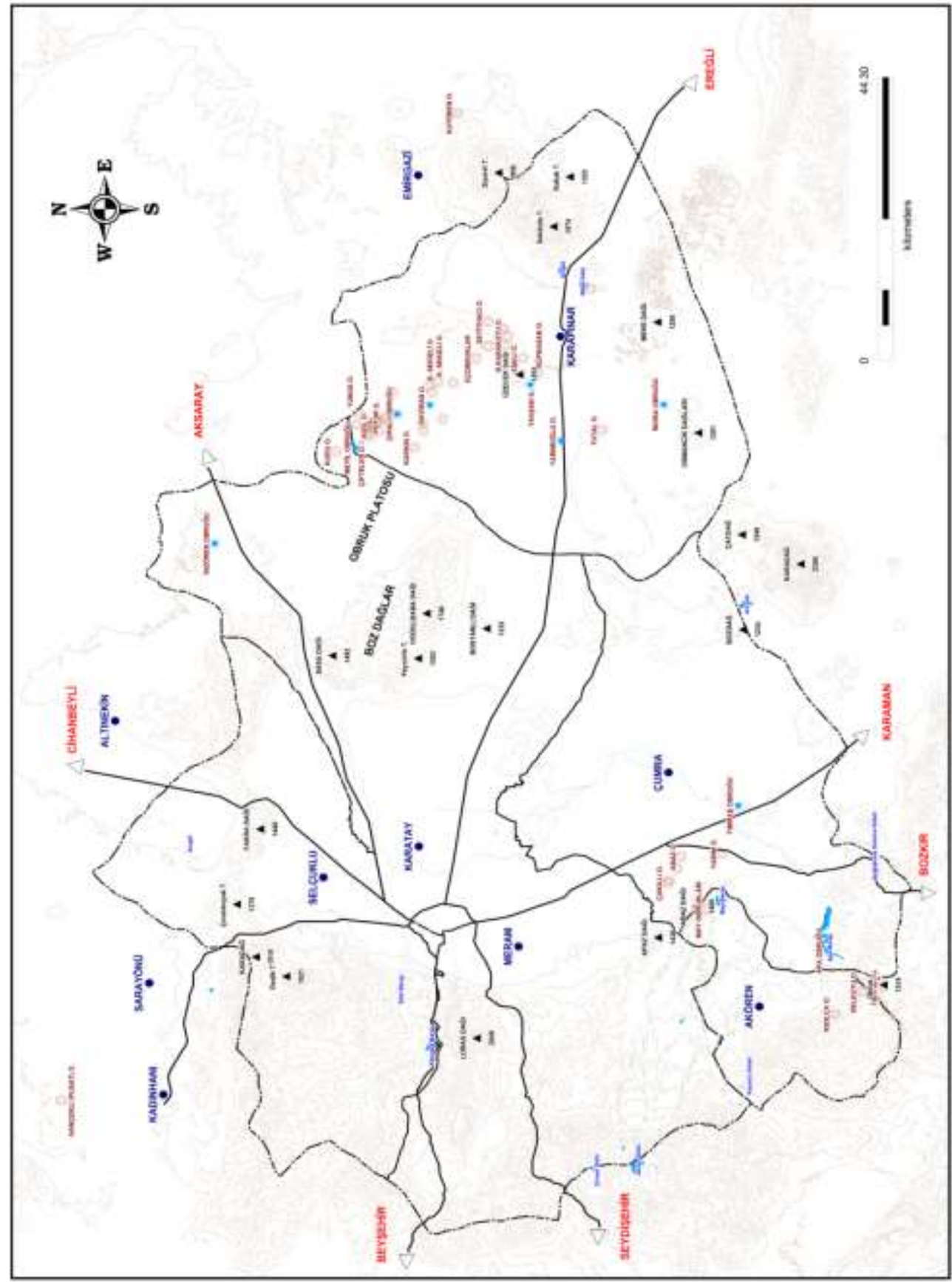

Şekil 2: Konya İli Obruklarının Dağılımı 


\section{OLUŞUM BAKIMINDAN GÜNCEL OBRUKLAR}

Konya İli'nde yakın tarihlerde oluşan toplam 43 obruktan 3'ü sulu 40'1 ise susuz obruktur (Tablo 1). Bu obruklardan 8'i arazi değerini düşürmesi nedeniyle kapatılmıştır.

\begin{tabular}{|c|c|c|c|c|c|c|c|c|}
\hline \multicolumn{9}{|c|}{ Tablo 1: Konya İli’nde Yakın Tarihlerde Oluşmuş Obrukların Özellikleri. } \\
\hline & Obruk Adı & İlçesi & Bulunduğu Yer & \begin{tabular}{|c|}
$\begin{array}{c}\text { Oluşum } \\
\text { Yılı }\end{array}$ \\
\end{tabular} & \begin{tabular}{|c|} 
Çapı (m) \\
Uz+Kıs \\
\end{tabular} & \begin{tabular}{|c|} 
Derinlik \\
(m)
\end{tabular} & \begin{tabular}{|c|} 
Yük. \\
(m)
\end{tabular} & $\begin{array}{c}\text { Su } \\
\text { Durumu }\end{array}$ \\
\hline 1 & İnoba Obruğu & Karapınar & İnoba Y. & 2008 & 29 & 42 & 1010 & Sulu \\
\hline 2 & Akkuyu Obruğu-I & Karapınar & Akkuyu Y. & 2007 & $19 \times 17$ & 2.5 & 1033 & Susuz \\
\hline 3 & Akkuyu Obruğu-II & Karapınar & Akkuyu Y. & 2008 & 16 & 1 & 1022 & Kapatılmış \\
\hline 4 & Yarımoğlu Obruğu & Karapınar & Akkuyu Y. & 2009 & 28 & 76 & 1010 & Sulu \\
\hline 5 & Akkuyu Obruğu-IV & Karapınar & Akkuyu Y. & 2010 & 16 & 1 & 1009 & Susuz \\
\hline 6 & Akkuyu Obruğu-V & Karapınar & Akkuyu Y. & 2012 & 15 & 0.7 & 1023 & Susuz \\
\hline 7 & Tutal Obruğu & Karapınar & Sirnık Mevkii & 2009 & 13 & 2 & 1010 & Susuz \\
\hline 8 & Yavşançukuru Obruğu & Karapınar & Yavşançukuru Y. & 2000 & 21 & 56 & 998 & Sulu \\
\hline 9 & Hanyıkı̆̆ı Obruğu & Karapınar & Hanyıkı̆̆g1 Y. & 2003 & $7.7 \times 5.6$ & 6 & 1059 & Susuz \\
\hline 10 & Nebili Obruğu-II & Karapınar & Nebili T. Batıs1 & 1972 & $18 \times 16$ & 70 & 1092 & Susuz \\
\hline 11 & Akviran Obruğu & Karapınar & Akviran Y. & 1977 & 24 & 80 & 1046 & Susuz \\
\hline 12 & Sekizli Küçük Obruk & Karapınar & Sekizli Y. & 1983 & 16 & 3.5 & 1030 & Susuz \\
\hline 13 & Sekizli Büyük Obruk & Karapınar & Sekizli Y. & 1995 & 55 & 26 & 1028 & Susuz \\
\hline 14 & Küpbasan Yeni Obr.-I & Karapınar & Küpbasan Y. & 2006 & 14 & 6 & 1001 & Kapatılmış \\
\hline 15 & Küpbasan Yeni Obr.-II & Karapınar & Küpbasan Y. & 2014 & 20 & 5 & 1003 & Susuz \\
\hline 16 & Eşeli Obruğu & Karapınar & Eşeli Y. & 2009 & 18 & 1.5 & 1035 & Susuz \\
\hline 17 & B.Karakuyu Direkli O. & Karapınar & B.Karakuyu Y. & 2012 & 25 & 1 & 1008 & Susuz \\
\hline 18 & B.Karakuyu Koçhan O. & Karapınar & B.Karakuyu Y. & 2011 & 14 & 2 & 1032 & Susuz \\
\hline 19 & B.Karakuyu Şenyurt O. & Karapınar & B.Karakuyu Y. & 2012 & 15 & 2.5 & 1032 & Susuz \\
\hline 20 & Aşıroğlu Obruğu-I & Karapınar & B.Karakuyu Y. & & 19 & 4 & 1005 & Susuz \\
\hline 21 & Aşıroğlu Obruğu-II & Karapınar & B.Karakuyu Y. & 2011 & 20 & 2 & 1008 & Susuz \\
\hline 22 & Aşıroğlu Obruğu-III & Karapınar & B.Karakuyu Y. & & 16 & 8 & 1007 & Susuz \\
\hline 23 & Köken Obruğu-I & Karapınar & Köken Y. & 2011 & 10 & 1 & 1005 & Susuz \\
\hline 24 & Köken Obruğu-II & Karapınar & Köken Y. & & 16 & 1 & 1012 & Susuz \\
\hline 25 & Köken Obruğu-III & Karapınar & Köken Y. & 2013 & 18 & 0.5 & 1006 & Susuz \\
\hline 26 & Seyithacı Obruğu-I & Karapınar & Seyithacı Y. & 2007 & $15 \times 12$ & 1 & 1011 & Susuz \\
\hline 27 & Seyithacı Obruğu-II & Karapınar & Seyithacı Y. & 2007 & $16 \times 13$ & 3 & 1010 & Susuz \\
\hline 28 & Seyithacı Obruğu-III & Karapınar & Seyithacı Y. & 2007 & $25 \times 22$ & 4 & 1011 & Susuz \\
\hline 29 & Seyithacı Obruğu-IV & Karapınar & Seyithacı Y. & 2008 & $17 \times 15$ & 2 & 1009 & Susuz \\
\hline 30 & Seyithacı Obruğu-V & Karapınar & Seyithacı Y. & 2008 & $14 \times 12$ & 4 & 1009 & Susuz \\
\hline 31 & Seyithacı Obruğu-VI & Karapınar & Seyithacı Y. & 2008 & 6 & 6 & 1012 & Susuz \\
\hline 32 & Seyithac1 Obruğu-VII & Karapınar & Seyithac1 Y. & 2009 & 13 & 5 & 1034 & \begin{tabular}{|l} 
Susuz \\
\end{tabular} \\
\hline 33 & Seyithacı Obruğu-VIII & Karapınar & Seyithac1 Y. & 2009 & 3 & 2 & 1010 & Kapatılmış \\
\hline 34 & Seyithacı Obruğu-IX & Karapınar & Seyithac1 Y. & 2012 & 16 & 0.5 & 1016 & Susuz \\
\hline 35 & Seyithacı Obruğu-X & Karapınar & Seyithacı Y. & 2014 & 30 & 1.5 & 1013 & Susuz \\
\hline 36 & İ.Çumra Abaz Obruğu & Çumra & Abaz Mevkii & 2012 & 10 & 8 & 1027 & Kapatılmış \\
\hline 37 & İ.Çumra Çakıllar-I & Çumra & Çakıllar Mevkii & 2006 & 5 & 9 & 1025 & Kapatılmış \\
\hline 38 & İ.Çumra Çakıllar-II & Çumra & Çakıllar Mevkii & 2008 & 4 & 7 & 1028 & Kapatılmış \\
\hline 39 & İ.Çumra Çakıllar-III & Çumra & Çakıllar Mevkii & 2009 & 2 & 4 & 1028 & Kapatılmış \\
\hline 40 & May Obruğu-I & Akören & May Barajı & 2002 & 70 & 10 & 1056 & Susuz \\
\hline 41 & May Obruğu-II & Akören & May Barajı & 2002 & 22 & 5 & 1055 & Susuz \\
\hline 42 & May Obruğu-III & Akören & May Barajı & 2002 & 11 & 3 & 1054 & Susuz \\
\hline 43 & Kadınhanı Hançerli O. & Kadınhanı & Pusat köyü & 2013 & $18 \times 13$ & 7 & 1004 & Kapatılmış \\
\hline
\end{tabular}




\subsection{INNOBA OBRUĞU}

İnoba Obruğu, Karapınar ilçe merkezine $21 \mathrm{~km}$ uzaklıktaki $\left(37^{\circ}\right.$ 34' 43" Kuzey - 33 $3^{\circ} 25^{\prime} 42^{\prime \prime}$ Doğu) İnoba yayla yerleşmesinin $40 \mathrm{~m}$ batısında yer alır (Fotoğraf 1). Obruk, 10 Kasım 2008 tarihinde kalker, kil ve marnlı formasyonlar içinde oluşmuştur. Deniz seviyesine göre $1010 \mathrm{~m}$ yükseklikte olan obruk, $29 \mathrm{~m}$ çapında ve $42 \mathrm{~m}$ derinliktedir (Fotoğraf 2).

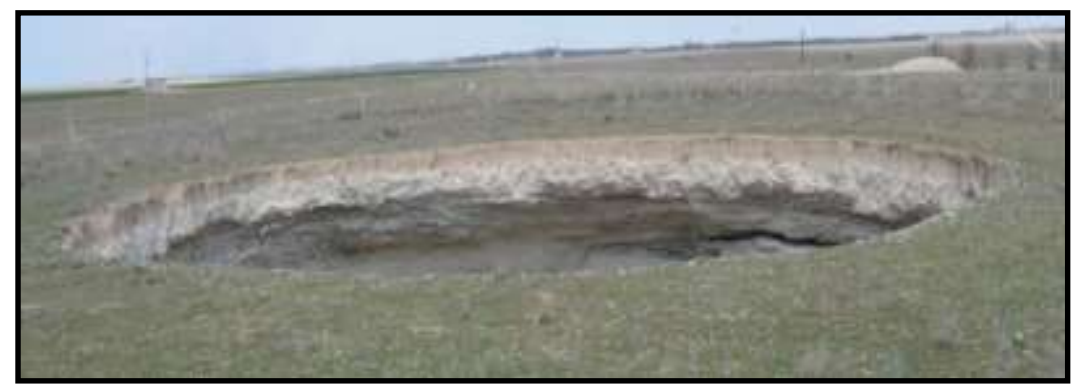

Fotoğraf 1: İnoba Obruğu'nun doğudan görünümü.

Oluşumu devam eden obruğun kenarlarındaki göçmelerle çapının daha da artması beklenmektedir. Bunda, kuşkusuz yeraltı sularındaki azalma ve karstik arazi yapısı da etkili olmaktadır. Obruğun yayla yerleşmesine yakın mesafede yer alması büyük bir tehlike arz etmektedir. Burada yaşayan ailelerden 7'si İnoba Obruğu'nun oluşumu sonrasında ilçe merkezine göç etmiştir.

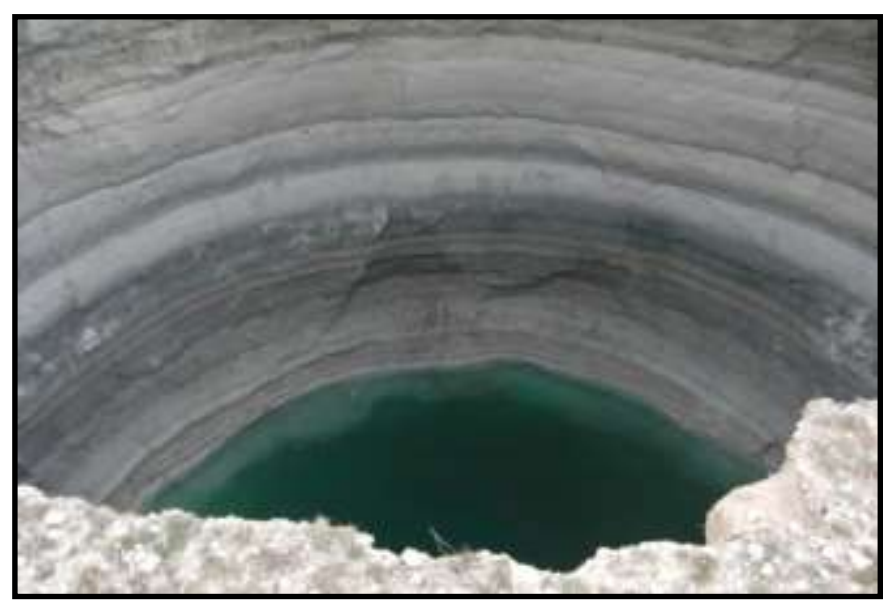

Fotoğraf 2: İnoba Obruğu ve su yüzeyi. 


\subsection{AKKUYU YAYLASI OBRUKLARI}

Karapınar - Konya karayolu kuzeyinde yer alan Akkuyu Yaylası 2007-2012 yılları arasında obruk oluşumu bakımından dikkat çeken yerlerden birisidir. Akkuyu Yaylas1, kuzeydeki plato sahası ile ova sahasının birleşim alanında bulunmaktadır. Yayla ve çevresindeki litolojiyi oluşturan formasyonlar, Kuaterner yaşlı gölsel depolardan meydana gelmiştir. 2007-2013 yılları arasında Akkuyu Yaylası'nın değişik mevkilerinde 5 obruk oluşmuştur. Bu obruklar oluşum yıllarına göre isimlendirilmiştir.

\subsection{AKKUYU OBRUĞU-I}

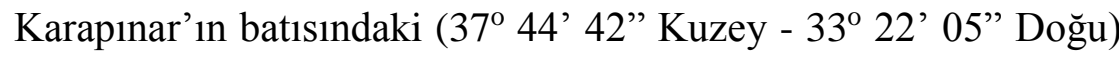
Akkuyu Yaylası'nın kuzeyinde yer alır. 2007 yılında Kuaterner yaşlı alüvyon örtü içerisinde oluşmuştur. Deniz seviyesine göre üst yüzey yüksekliği $1033 \mathrm{~m}$, derinliği $2.5 \mathrm{~m}$ olan obruğun uzun eksen çap $19 \mathrm{~m}$ ve kısa eksen çap1 ise $17 \mathrm{~m}$ dir. Kabaca dairesel şekilli obruğun yamaçlarında obruğun gelişimini gösteren çatlak ve çökmeler mevcuttur (Fotoğraf 3).

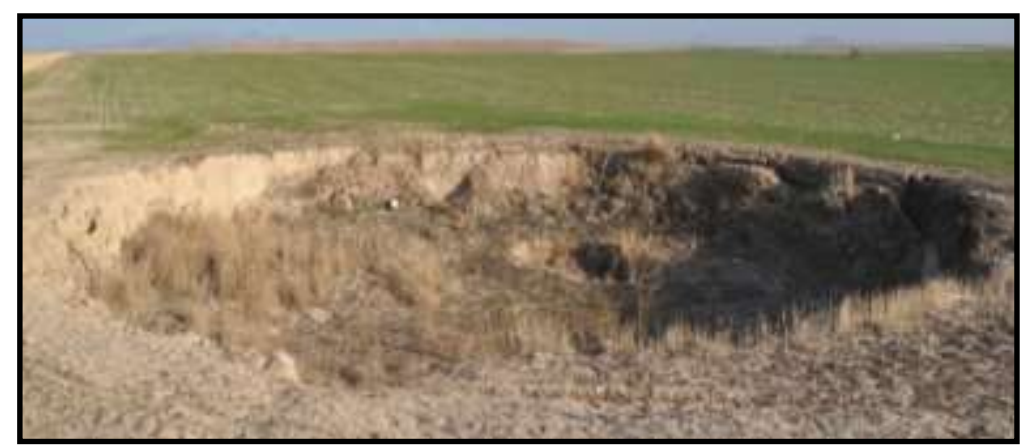

Fotoğraf 3: Akkuyu Obruğu-I

\subsection{AKKUYU OBRUĞU-II}

Akkuyu Obruğu-II, Akkuyu Yaylası'nın kuzeydoğusunda (37 43' 52" Kuzey - 330 23' 01" Doğu) yer alır. 2008'de alüvyon örtü içerisinde oluşan obruk, bugün kapatılmıştır. Yayla sakinlerinin gösterdiği yerde yapılan incelemelere göre obruğun deniz seviyesine göre yüksekliği $1022 \mathrm{~m}$, derinliği $1 \mathrm{~m}$, ortalama çapı ise $16 \mathrm{~m}$ olarak belirlenmiştir. 


\subsection{YARIMOĞLU OBRUĞU (AKKUYU-III)}

Karapınar ilçe merkezinin $17.2 \mathrm{~km}$ batısındaki (37 $44^{\circ}$ '54" Kuzey - 332 21'56” Doğu) Akkuyu Yaylası'nda yer alır (Fotoğraf 4).

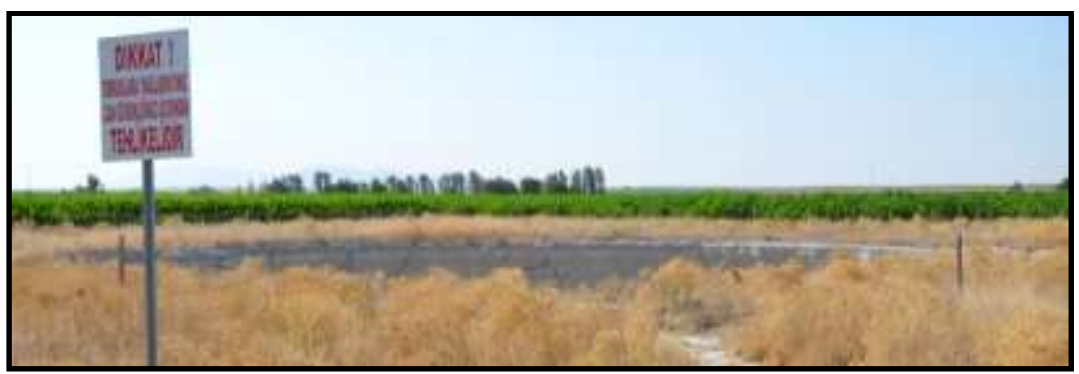

Fotoğraf 4: Yarımoğlu Obruğu'nun uzaktan görünümü

Obruk, 07 Şubat 2009 tarihinde toprak, kil ve marnlı alüvyon formasyonlar içerisinde oluşmuştur. Deniz seviyesine göre üst yüzey yüksekliği $1010 \mathrm{~m}$ dir. Obruk çevresinde özellikle batı kesimde yer alan iç bükey göçmeler ve derin çatlaklar obruğun daha da genişleyeceğini göstermektedir. İlk oluştuğunda obruğun çap1 $25 \mathrm{~m}$ iken, bugün bu çap $28 \mathrm{~m}$ ye kadar çıkmıştır. Obruğun yaklaşık $49 \mathrm{~m}$ den sonraki kısmında su bulunmaktadır (Fotoğraf 5, 6). Yarımoğlu Obruğu, Konya-Adana karayoluna çok yakın olduğu için çok sayıda ziyaretçi çekmektedir. Obruğun kenarı basit bir dikenli tel ile çevrilmiştir. Ancak bu dikenli tel koruması zamanla özelliğini kaybetmiştir. Obruğa gelen insanlar için ciddi bir tehlike söz konusudur. Çünkü obruğun kenarlarında çatlaklar ve göçmeler her gün olabilmektedir. En kısa zamanda ilgili kurum ve yetkililer tarafindan bu koruma tedbirlerinin arttırılması gerekmektedir.
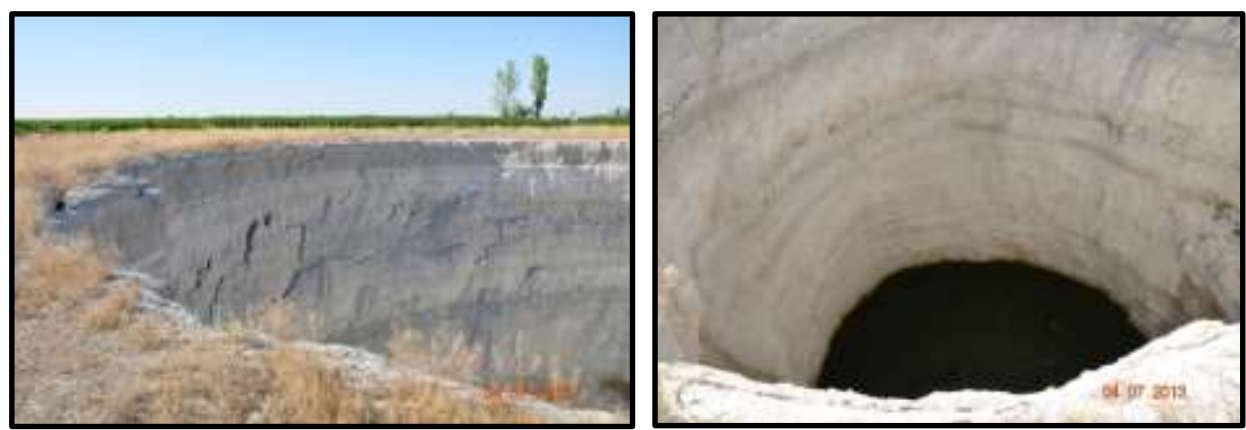

Fotoğraf 5-6: Yarımoğlu Obruğu'nun çeşitli yönlerden görünümü. 


\subsection{AKKUYU OBRUĞU-IV}

Karapınar ilçe merkezinin batısındaki ( $37^{\circ} 43^{\prime} 32^{\prime \prime}$ Kuzey - $33^{\circ}$ 21' 27" Doğu) Akkuyu Yaylası'nda yer alır. 2010 yılında alüvyon örtü içerisinde oluşmuştur. Deniz seviyesine göre üst yüzey yüksekliği 1009 $\mathrm{m}$, derinliği $1 \mathrm{~m}$, ortalama çapı ise $16 \mathrm{~m}$ dir. Dairesel şekilli obruğun içi otlarla doludur (Fotoğraf 7).

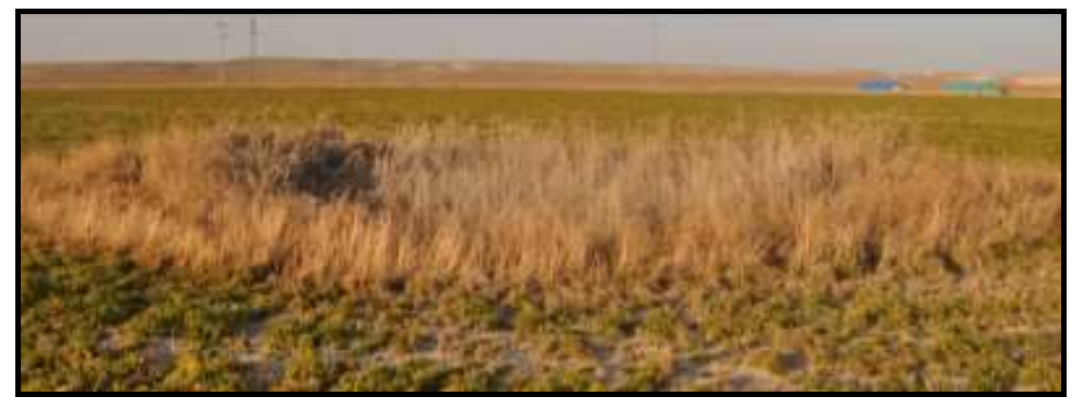

Fotoğraf 7: Akkuyu Obruğu-IV'ün güneyden görünümü

\subsection{AKKUYU OBRUĞU-V}

Karapınar ilçe merkezinin batısında ( $37^{\circ} 44^{\prime} 15^{\prime \prime}$ Kuzey - $33^{\circ} 21^{\text {' }}$ 42” Doğu) Akkuyu Yaylası'nda yer alır. 2012 yılında alüvyon örtü içerisinde oluşmuştur. Deniz seviyesine göre üst yüzey yüksekliği 1023 $\mathrm{m}$, derinliği $0.7 \mathrm{~m}$, ortalama çapı ise $15 \mathrm{~m}$ dir. Derinliği az olan obruğun kenar çatlakları yayla sakinlerinin ifadesine göre her geçen gün genişlemektedir.

\subsection{TUTAL OBRUĞU}

Karapınar'ın $20 \mathrm{~km}$ güneybatısındaki $\left(37^{\circ} 35^{\prime} 08^{\prime \prime}\right.$ Kuzey - $33^{\circ}$ 23' 49” Doğu) Sırnık Mevkii'nde, Ağustos 2009'da meydana gelmiştir. Obruk, Kuaterner yaşlı gölsel sedimentler içerisinde oluşmuştur. Deniz seviyesine göre yüksekliği $1010 \mathrm{~m}$ dir. İlk oluştuğunda yaklaşık $1.5 \mathrm{~m}$ derinliğinde, $10 \mathrm{~m}$ çapında iken bugün obruğun derinliği $2 \mathrm{~m}$ ve çapı da $13 \mathrm{~m}$ ye çıkmıştır. Obruğun kenarlarında çevrede biriken suları drene eden düden özelliği taşıyan yarıklar vardır. Gerek yamaçlardaki göçmeler gerekse bu açılan çatlaklardaki değişimler, obruğun gelişiminin devam ettirdiğini göstermektedir (Fotoğraf 8). Ayrıca obruk yamaçlarında gölsel sedimentler içinde tatlı su fosilleri görülmektedir. 


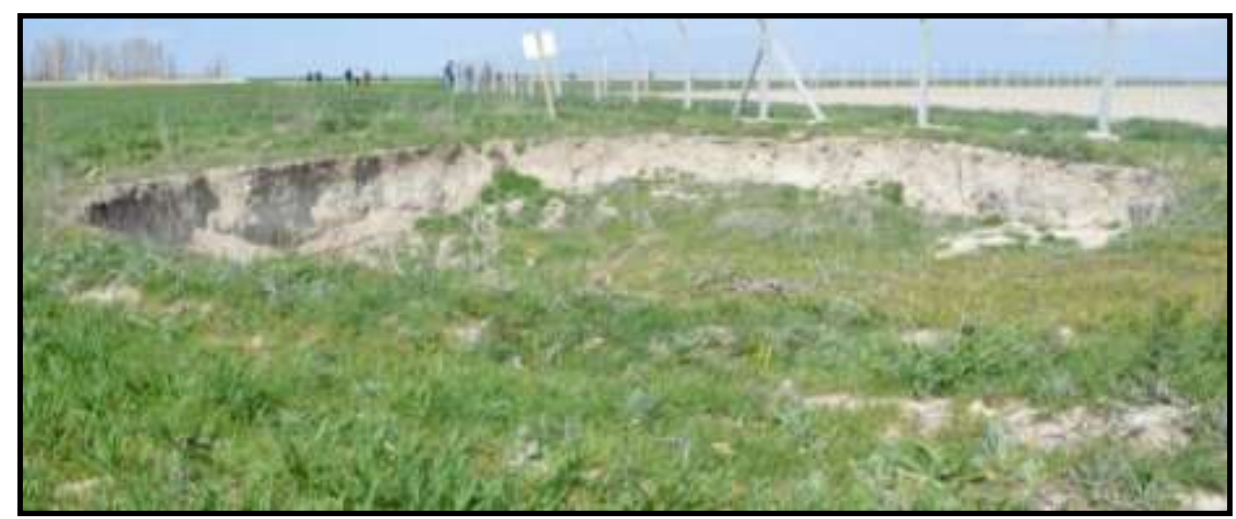

Fotoğraf 8: Tutal Obruğu’nun güneydoğudan görünümü

\subsection{YAVŞANÇUKURU OBRUĞU}

Karapınar'in $8.5 \mathrm{~km}$ kuzeybatısında ( $37^{\circ} 44^{\prime} 55^{\prime \prime}$ Kuzey - $33^{\circ} 28^{\prime}$ 34" Doğu), Yavşançukuru Yaylası'nın $1 \mathrm{~km}$ doğusunda yer alır. Deniz seviyesine göre üst yüzey yüksekliği 998 m dir. Ekim 2013'te yapılan ölçümlere göre obruğun çap $12 \mathrm{~m}$, çevresi $70 \mathrm{~m}$ ve derinliği ise $56 \mathrm{~m}$ dir. Etrafı korumasız olan bu derin obruk, insan ve diğer canlılar için çok tehlikelidir. En kısa zamanda bu obruk kenarına koruma tedbirleri ve uyarı levhaları konulmalıdır (Fotoğraf 9).

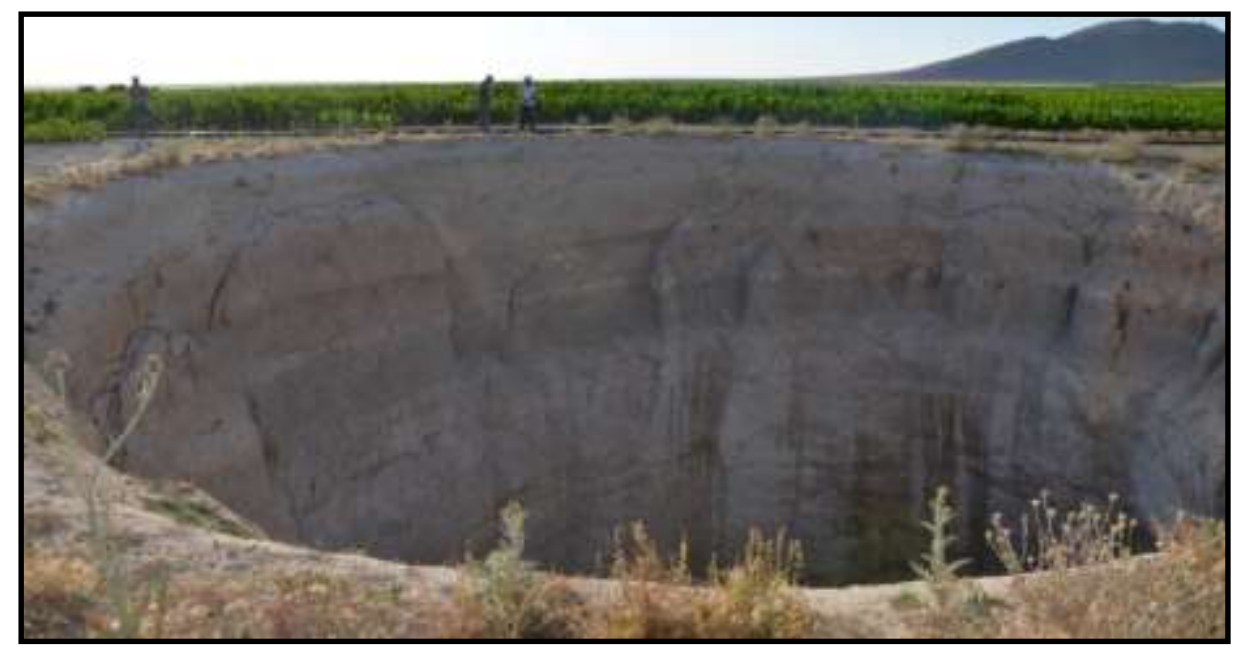

Fotoğraf 9: Yavşançukuru Obruğu'nun güneyden görünümü. 


\subsection{HANYIKIĞI OBRUĞU}

Karapınar'1n 12.5 km kuzeybatısında yer alır (37 47' 40" Kuzey

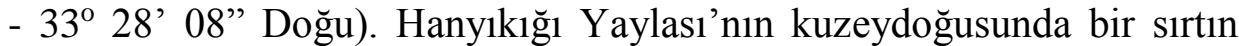
üzerinde 2003 yılında oluşmuştur. Obruk, Üst Miosen - Pliosen yaşlı formasyonlar içerisinde oluşmuştur. Deniz seviyesine göre üst yüzey yüksekliği $1059 \mathrm{~m}$, derinliği $6 \mathrm{~m}$, çevresi $20 \mathrm{~m}$ dir. Obruğun uzun ekseni $7.7 \mathrm{~m}$, kısa ekseni ise $5.6 \mathrm{~m}$ dir. Obruğun doğu ve batı yamaçlarında, içbükey oyulma görülür (Fotoğraf 10 ). Bu oyulmalara bağlı oluşan enkaz, tabanı örtmektedir. Ayrıca obruğun içerisinde nemli bir ortam olduğu için burası güvercinlerin yaşama alanı halindedir. Tabanda güvercin gübre katmanları birikmiştir. Obruk çevresinde koruyucu herhangi bir uyarı ve tedbir yoktur. En kısa zamanda bu obruk kenarına koruma tedbirleri ve uyarı levhaları konulmalıdır.

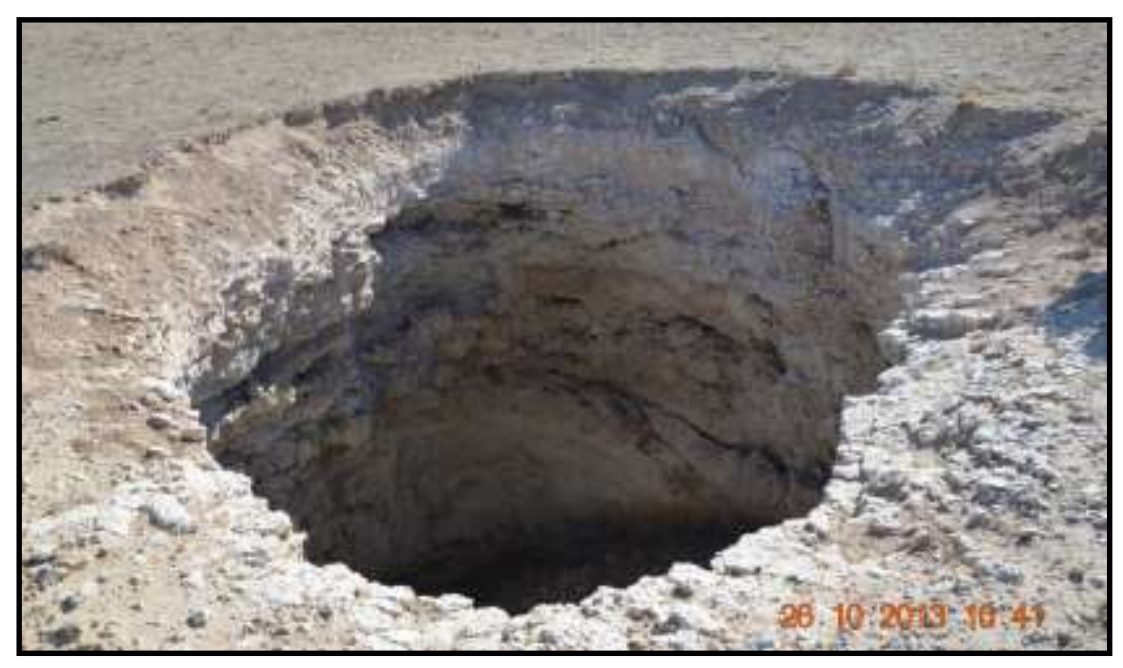

Fotoğraf 10: Hanyıkığı Obruğu

\subsection{NEBİLİ OBRUĞU-II (NACIYYE ABA OBRUĞU)}

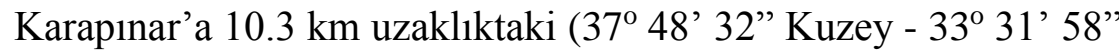
Doğu) obruk, Büyükkarakuyu Yaylası'nın kuzeyinde yer alır. Obruk yamaçları, yukarıdan aşağıya doğru toprak, marn ve daha derinde kalker örtüden oluşmaktadır. Deniz seviyesine göre üst yüzey yüksekliği 1092 $\mathrm{m}$, derinliği $70 \mathrm{~m}$ dir. Oluşumundan itibaren sulu olan obruk, son y1llarda yeraltı su seviyesinin daha derinlere inmesi nedeniyle susuz bir obruk 
haline gelmiştir. Kabaca elips şekilli obruğun çevresi $62 \mathrm{~m}$, uzun ekseni $18 \mathrm{~m}$, k1sa ekseni ise $16 \mathrm{~m}$ olarak ölçülmüştür. Obruk, içbükey yamaçlarıyla dikkati çeker (Fotoğraf 11). Bu durum güvercinlerin barınmalarına da imkân verir. Etrafı korumasız olan obruk canlılar için tehlike arz etmektedir.

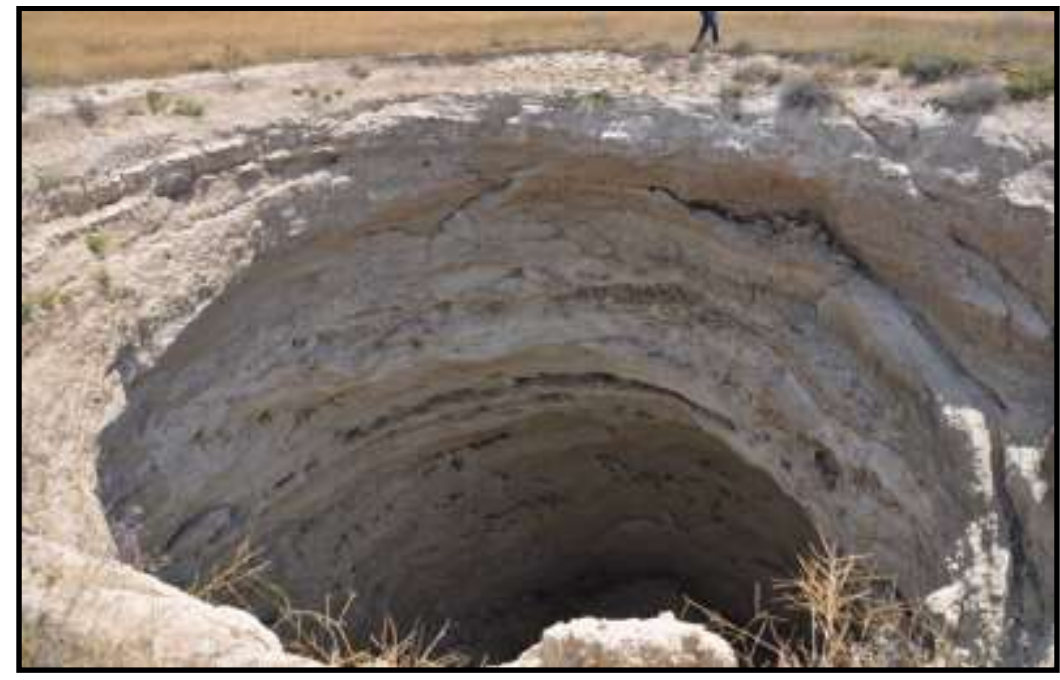

Fotoğraf 11: Nebili Obruğu-II

\subsection{AKVIIRAN OBRUĞU}

Karapinar'in $25.6 \mathrm{~km}$ kuzeybatisinda (37 $37^{\circ}$ ' 40" Kuzey - $33^{\circ}$ 25' 30" Doğu), Akviran Yaylası'nın kuzeyinde yer alır. Obruk Üst Miosen-Pliosen formasyonları içinde 1977 yılında oluşmuştur (Fotoğraf 12). Deniz seviyesine göre üst yüzey yüksekliği $1046 \mathrm{~m}$, derinliği $80 \mathrm{~m}$, çevresi $82 \mathrm{~m}$, çapı da $24 \mathrm{~m}$ dir. Obruğun kalkerli tabakalarında, yeraltı sularının oluşturduğu çözünme boşlukları bulunur. Güvercinler bu boşluklara yuvalar yapmıştır. Bu nedenle obruk, Güvercin Obruğu olarak da bilinmektedir. Obruk üst yüzeyi ile su seviyesi arasında $56 \mathrm{~m}$ lik yükselti farkı vardır. $\mathrm{Bu} 56 \mathrm{~m}$ lik derinlikten sonra su seviyesi başlamaktadır. Buradaki suyun derinliğinin yaklaşık $24 \mathrm{~m}$ olduğu sanılmaktadır. Obruğun ağız kısmı dar, tabanı geniştir. Etrafi korumasız olan obruk, insan ve diğer canlılar için tehlike arz etmektedir. Akviran Obruğu'nun güneyinde 2007 yılında $2 \mathrm{~m}$ çapında ve $0.5 \mathrm{~m}$ derinliğinde obruk görüntüsü veren bir çökme meydana gelmiştir. 


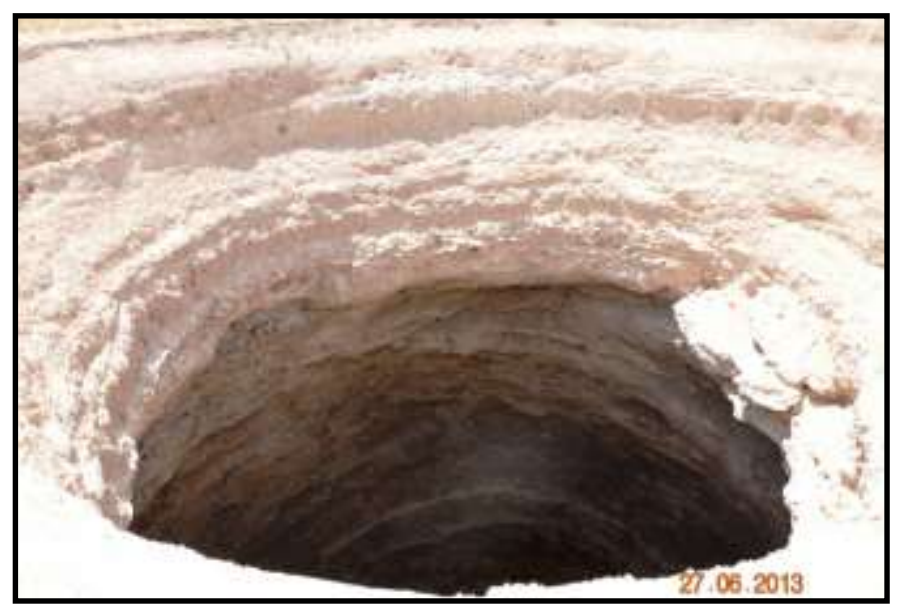

Fotoğraf 12: Akviran Obruğu

\subsection{SEKİZLİ KÜÇÜK OBRUK}

Karapınar'ın $18 \mathrm{~km}$ kuzeybatısındaki ( $37^{\circ} 52^{\prime} 36^{\prime \prime}$ Kuzey - $33^{\circ}$ 28 ' 05" Doğu), Sekizli Yaylası'nın kuzeydoğusunda yer alır. Obruk, alüvyon örtü formasyonları içerisinde oluşmuştur. Deniz seviyesine göre üst yüzey yüksekliği $1030 \mathrm{~m}$, derinliği $3.5 \mathrm{~m}$, çevresi $60 \mathrm{~m}$, ortalama çap1 ise $16 \mathrm{~m}$ dir. Yaklaşık 30 yıl önce oluşan obruğun kenarları büyük ölçüde tahrip olmuş ve kenarlarından göçen malzemeler obruk tabanında birikmiştir.

\subsection{SEKİZLİ BÜYÜK (ÇOBAN) OBRUK}

Karapınar'1n 21.55 km kuzeybatısındaki (37 $36^{\circ}$ '22" Kuzey - $33^{\circ}$ 27' 49” Doğu), Büyüksekizli Yaylası'nın kuzeydoğusunda yer alır. Obruk, alüvyon örtü formasyonları içerisinde oluşmuştur. Deniz seviyesine göre üst yüzey yüksekliği $1028 \mathrm{~m}$, derinliği $26 \mathrm{~m}$, çevresi 185 $\mathrm{m}$, ortalama çapı ise $55 \mathrm{~m}$ dir. Obruğun doğu ve batı yamaçlarında derin çatlaklar mevcuttur. Halen yamaçlarında göçmeler olduğu için obruğun çapı giderek genişlerken, derinliği de yamaçlardan gelen malzemelerle dolgulanarak azalmaktadır (Fotoğraf 13). Obruk çevresinde dikenli tel ile bir koruma önlemi alınmış olsa da bu dikenli tel direkleri yıkılmıştır. Nitekim obruk oluştuktan sonra Şamil ismindeki bir çoban obruğa düşmüş ve kendi imkânları ile 3 günde kurtulmuştur. Bazı kayıtlarda bu obruk Çoban Şamil Obruğu veya Kolca Obruğu olarak da geçmektedir. 
Bu obruk, Sekizli Yaylası'na ait merada olduğu için Sekizli Yaylası Büyük Obruk şeklinde isimlendirilmesi daha uygun olmaktadır.

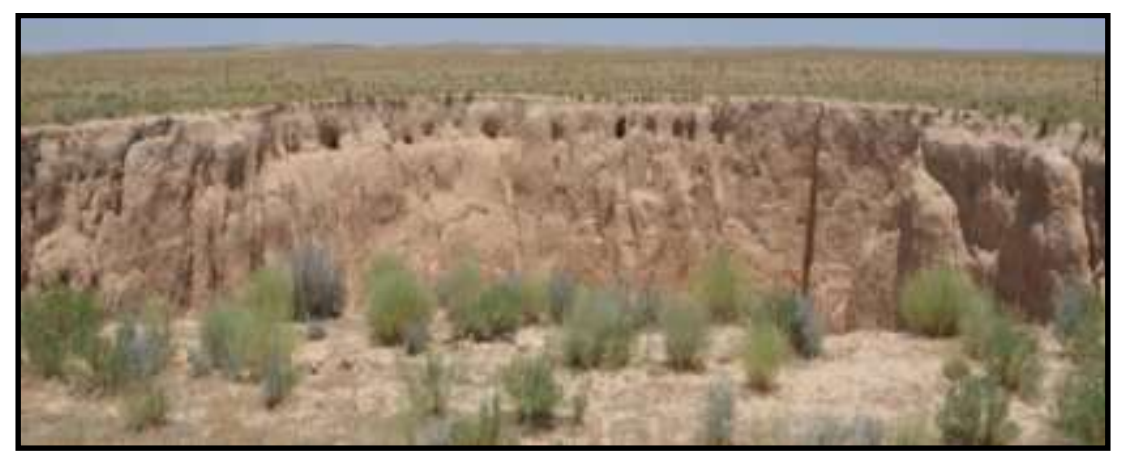

Fotoğraf 13: Sekizli Büyük Obruğun güneyden görünümü

\subsection{EŞELİ OBRUĞU}

Karapınar'in 7.7 km kuzeybatısında ( $37^{\circ} 46^{\prime} 36^{\prime \prime}$ Kuzey - 33 30' 47” Doğu), Eşeli Yaylası'nın kuzeydoğusunda yer alır. 2009 yılı Şubat ayında alüvyon depolar içerisinde oluşan bir obruktur (Fotoğraf 14). Deniz seviyesine göre üst yüzey yüksekliği $1035 \mathrm{~m}$, derinliği $1.5 \mathrm{~m}$, ortalama çap1 $18 \mathrm{~m}$, çevresi ise $60 \mathrm{~m}$ dir. Obruğun oluşumunun devam etmesi yayla yerleşmesinde yaşayan insanları tedirgin etmektedir.

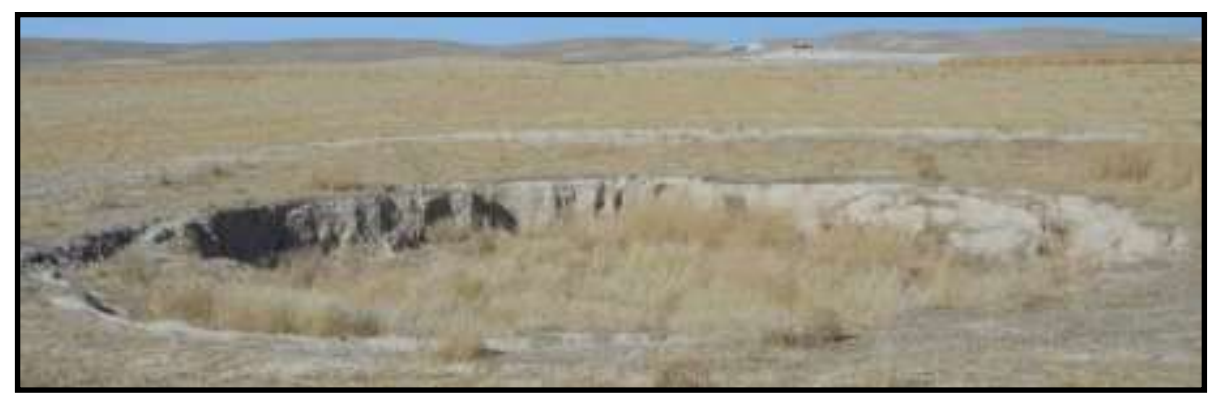

Fotoğraf 14: Eşeli Yaylası 'nın kuzeydoğusundaki Eşeli Obruk

Eşeli Yaylası'nın doğusunda 2012 yılında $1 \mathrm{~m}$ derinliğinde ikinci bir obruk daha oluşmuştur. Ancak bu obruk, tarlanın tam ortasında olduğu için kapatılmıştır. Tarla sahibi tedirgin olmakla beraber sulamalı tarıma devam etmektedir. Tarla sahibinin verdiği bilgiye göre obruğun bulunduğu yerin coğrafi koordinat $37^{\circ} 46^{\prime} 10^{\prime \prime}$ Kuzey ve $33^{\circ} 31^{\prime} 35^{\prime}$ " Doğu olarak tespit edilmiştir. 


\subsection{KÜPBASAN YENİ OBRUK-I}

Karapınar'ın 5 km kuzeybatısındaki (37 43' 99”' Kuzey - 32 $29^{\circ}$ ' 49" Doğu), Küpbasan Yaylası'nda meydana gelen bir obruktur. Nisan 2006 alüvyon depolar içerisinde oluşmuştur. Deniz seviyesine göre üst yüzey yüksekliği $1001 \mathrm{~m}$, derinliği $6 \mathrm{~m}$, ortalama çapı $14 \mathrm{~m}$, çevresi ise $32 \mathrm{~m}$ dir. Obruğun büyük bir kısmı hafriyatla doldurulmuştur (Fotoğraf 15). Yaylada yaşayan insanlar, obruk oluşumu esnasında büyük bir gürültü duyduklarını ve deprem olduğunu zannettiklerini belirtmişlerdir. $\mathrm{Bu}$ esnada obruk çevresindeki yayla meskenlerinin duvarlarında sarsıntı nedeniyle küçük çatlaklar oluşmuştur. Obruğun yayla yerleşmesinde olması burada yaşayan insanların korkmasına neden olmaktadır.

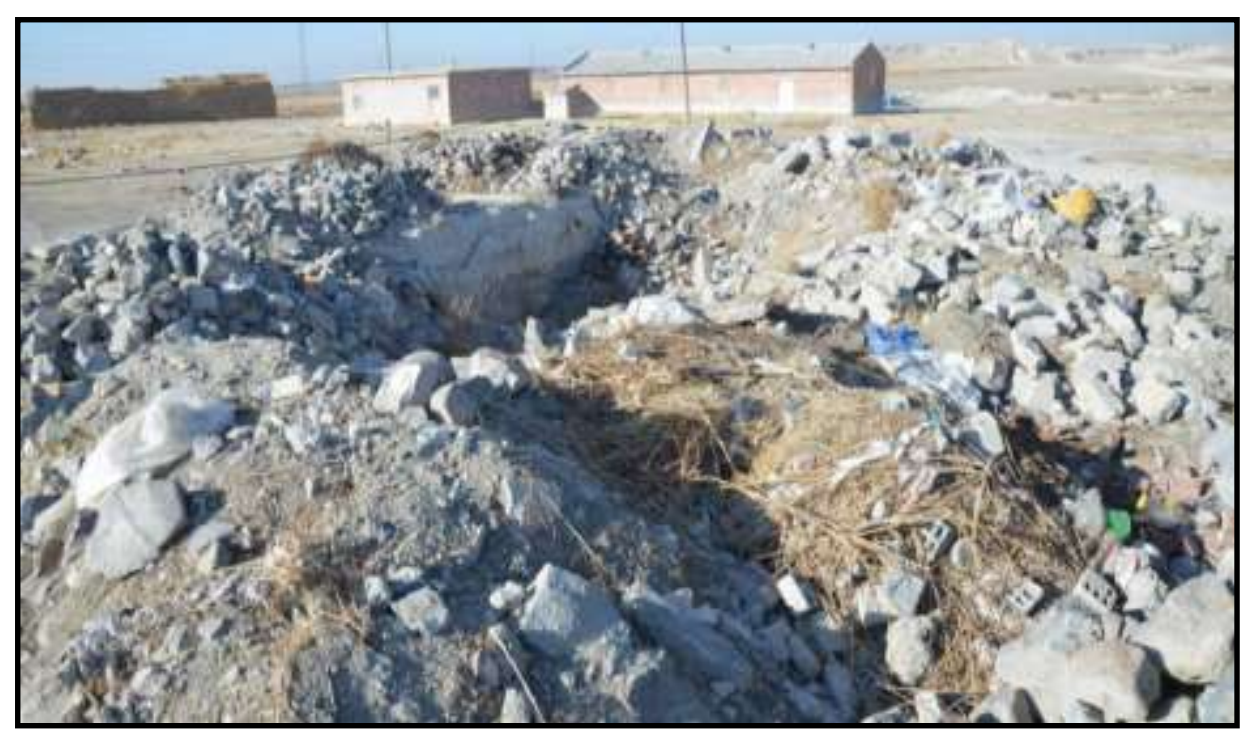

Fotoğraf 15: Küpbasan Yaylası'nda hafriyatla doldurulan Yeni Obruk-I

\subsection{KÜPBASAN YENİ OBRUK-II}

Küpbasan Yaylası'nda Haziran 2014 tarihinde alüvyon örtü içerisinde ikinci bir obruk daha oluşmuştur. Küpbasan Yeni Obruk-II olarak adlandırılan obruğun deniz seviyesine göre üst yüzey yüksekliği $1003 \mathrm{~m}$, çap $20 \mathrm{~m}$, derinliği ise $5 \mathrm{~m}$ olarak ölçülmüştür (Fotoğraf 16). 


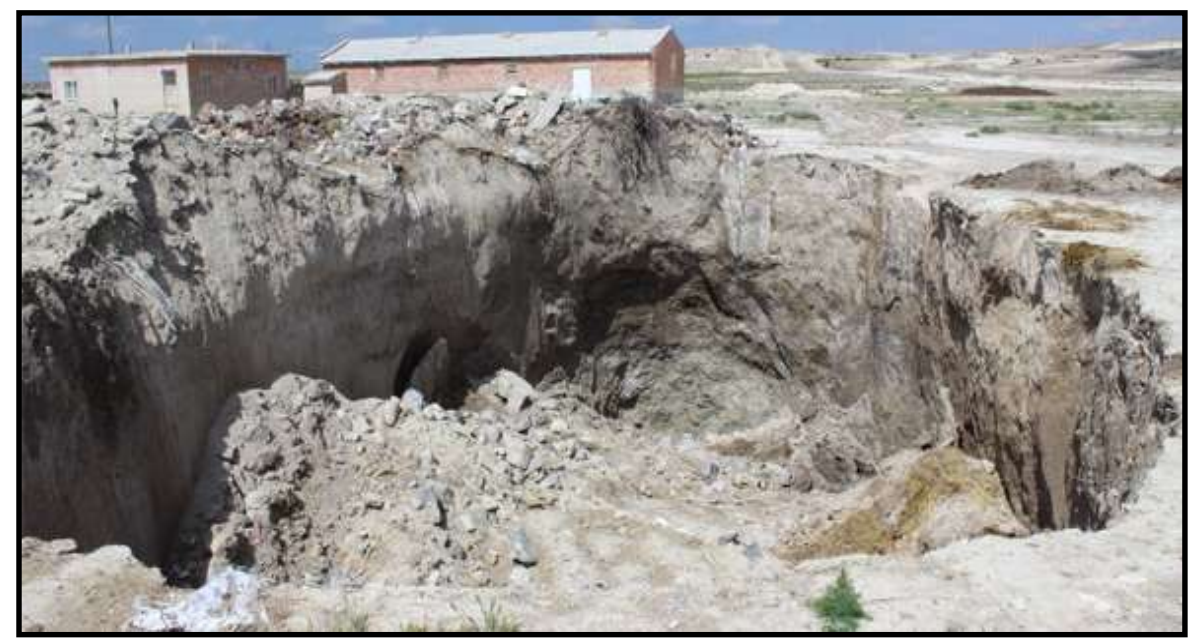

Fotoğraf 16: Küpbasan Yeni Obruk-II

\subsection{BÜYÜKKARAKUYU-DİREKLİ OBRUK}

Karapınar'1n 6.5 km kuzeyindeki ( $37^{\circ} 46^{\prime} 40^{\prime \prime}$ Kuzey - $33^{\circ} 32^{\prime}$ 39” Doğu), Büyükkarakuyu Yaylası'nda yer alır. 2012 yılında alüvyon örtü içerisinde oluşmuştur. Deniz seviyesine göre üst yüzey yüksekliği $1008 \mathrm{~m}$, derinliği $1 \mathrm{~m}$, ortalama çap1 $25 \mathrm{~m}$, çevresi ise $160 \mathrm{~m}$ dir. Çevresindeki derin çatlak sistemleri, obruğun hala oluşumunu devam ettirdiğini göstermektedir (Fotoğraf 17). Obruğun tam ortasında yayla yerleşmelerinin elektrik hattını taşıyan bir elektrik direği bulunmaktadır. Bu nedenle obruğa Direkli Obruk adı verilmiştir.

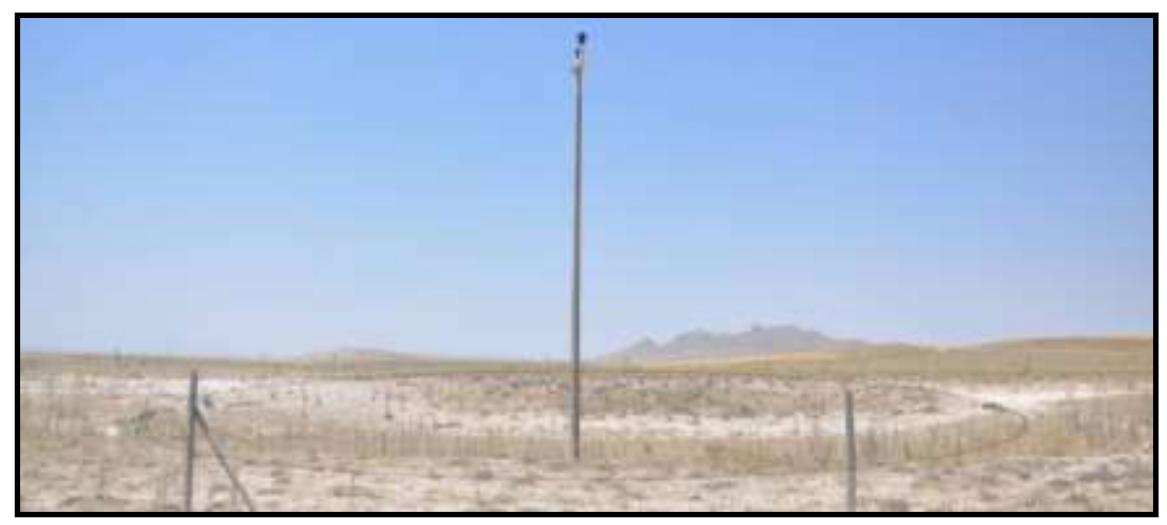

Fotoğraf 17: Büyükkarakuyu Yaylası'nın kuzeyinde Direkli Obruk 


\subsection{BÜYÜKKARAKUYU-ŞENYURT OBRUĞU}

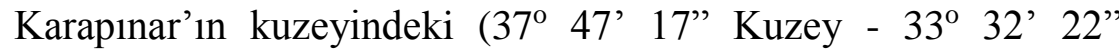
Doğu), Büyükkarakuyu Yaylası'nın kuzeybatısında yer alır. Obruk, 2011 yılında alüvyon örtü içerisinde Şenyurt ailesine ait tarlada oluşmuştur. Deniz seviyesine göre üst yüzey yüksekliği $1032 \mathrm{~m}$, derinliği $2.5 \mathrm{~m}$, ortalama çap $15 \mathrm{~m}$, çevresi ise $52 \mathrm{~m}$ dir. Çevresindeki $4 \mathrm{~m}$ yi bulan derin çatlaklar, obruğun hala oluşumunun devam ettiğini göstermektedir.

\subsection{BÜYÜKKARAKUYU-KOÇHAN OBRUĞU}

Karapınar'1n kuzeyindeki (370 47'09" Kuzey - 330 32'09" Doğu), Büyükkarakuyu Yaylası'nın kuzeybatısında yer alır. 2011 yılında obruk, alüvyon örtü içerisinde Koçhan ailesine ait bir yonca tarlasında oluşmuştur. Deniz seviyesine göre üst yüzey yüksekliği $1032 \mathrm{~m}$, derinliği $2 \mathrm{~m}$, ortalama çap $14 \mathrm{~m}$, çevresi ise $74 \mathrm{~m}$ dir. Çevresindeki derin çatlaklar obruğun oluşumunun devam ettiğini göstermektedir (Fotoğraf 18).

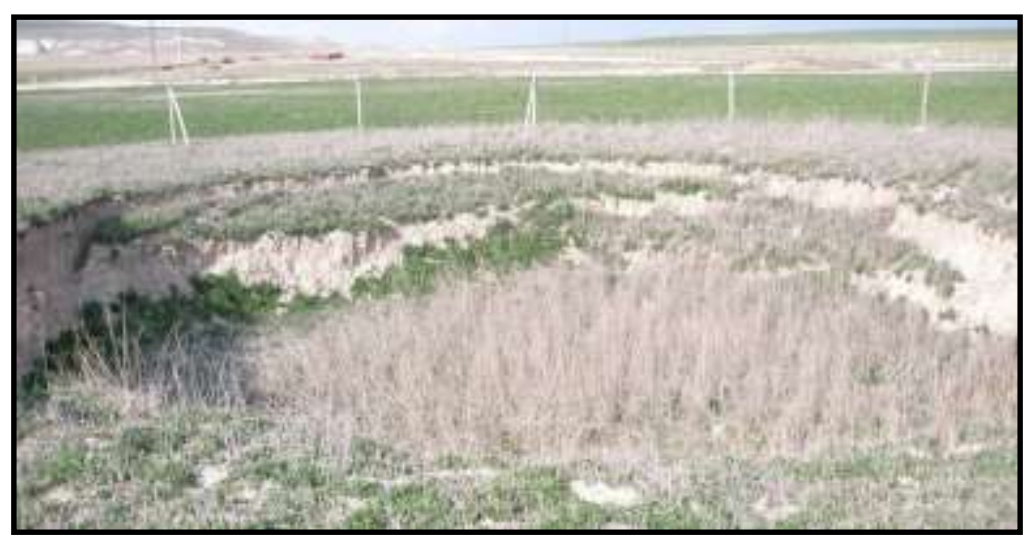

Fotoğraf 18: Büyükkarakuyu Yaylası Koçhan Obruğu

Koçhan Obruğu'nun $50 \mathrm{~m}$ güneyinde, Aralık 2013'te $10 \mathrm{~m}$ çapında, $20 \mathrm{~cm}$ derinliğinde ikinci bir obruk daha oluşmuştur.

\subsection{KÜÇÜKKARAKUYU-AŞIROĞLU OBRUĞU-I}

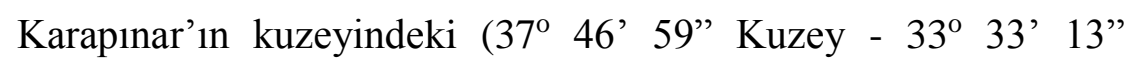
Doğu), Küçükkarakuyu Yaylası'nda Aşıroğlu ailesine ait tarla içinde yer alır. Obruk, 2010 yılında gölsel depolar içerisinde Yaşça Fayı'na bağlı olarak oluşmuştur. Deniz seviyesine göre yüksekliği 1005 m, derinliği 4 
m, çap $19 \mathrm{~m}$, çevresi ise $45 \mathrm{~m}$ dir. Daire şeklindeki obruğun kuzeydoğu ve güneybatı yamaçlarında derin çatlaklar bulunmaktadır (Fotoğraf 19).

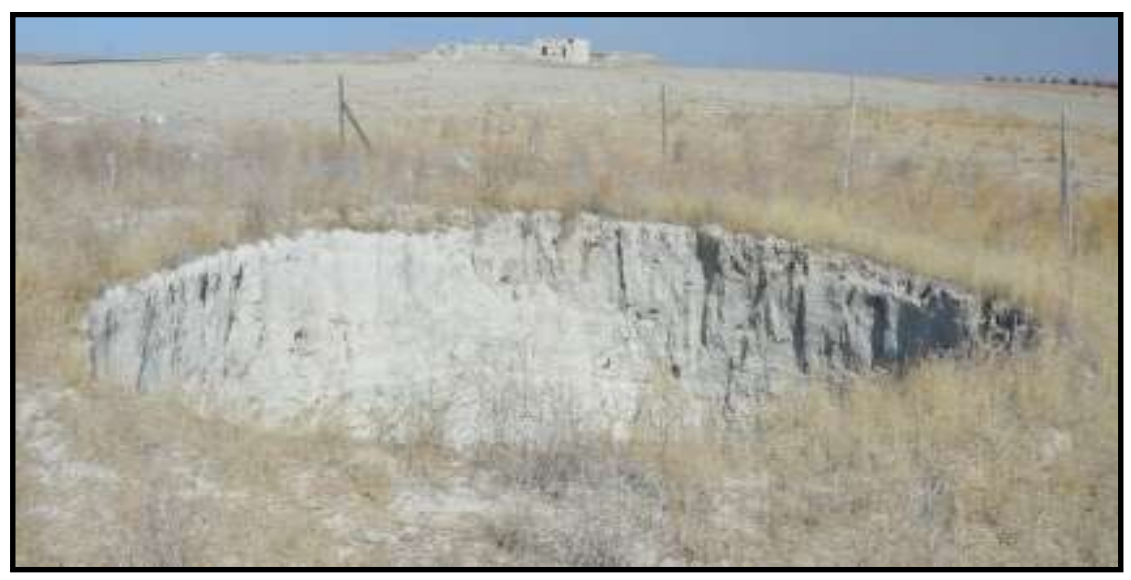

Fotoğraf 19: Küçükkarakuyu Yaylast-Aşıroğlu Obruğu I

\subsection{KÜÇÜKKARAKUYU-AŞIROĞLU OBRUĞU-II}

Karapınar'1n kuzeyinde ( $37^{\circ} 47^{\prime} 15^{\prime \prime}$ Kuzey - 33 33' 14” Doğu), Küçükkarakuyu Yaylası'nda yine Aşıroğlu ailesine ait tarla içinde yer alır. Obruk, 2011 yılında marnlı gölsel depolar içerisinde Yaşça Fayı'na bağlı olarak oluşmuştur. Deniz seviyesine göre üst yüzey yüksekliği 1008 $\mathrm{m}$, derinliği $2 \mathrm{~m}$, ortalama çap1 $20 \mathrm{~m}$, çevresi ise $50 \mathrm{~m}$ dir (Fotoğraf 20). Daire şeklindeki obruğun batı ve güney yamaçlarında diklikler, kuzey ve doğu yamaçlarında da derin çatlaklar vardır.

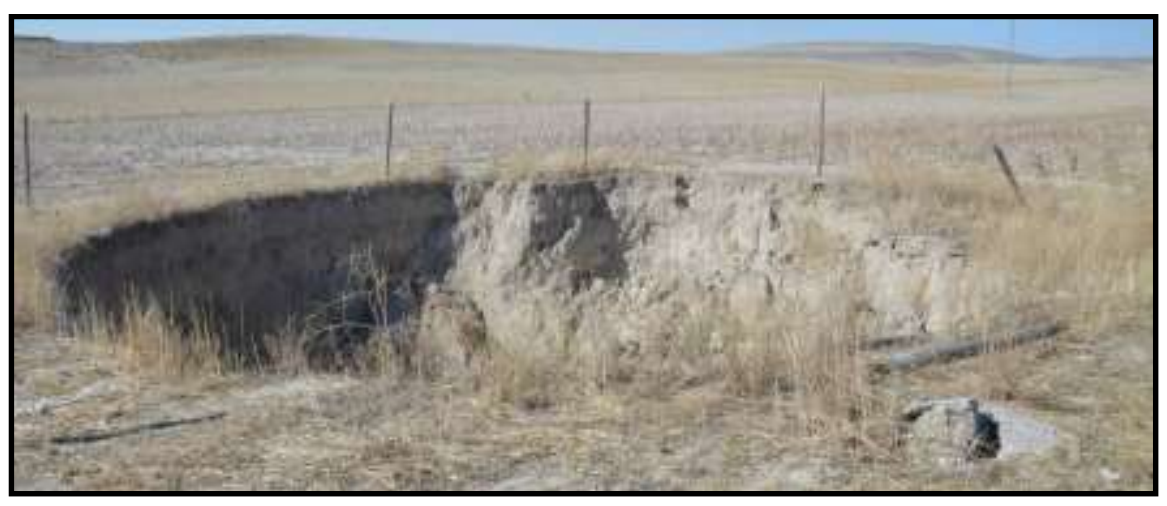

Fotoğraf 20: Küçükkarakuyu Yaylast-Aşıroğlu Obruğu 


\subsection{KÜÇÜKKARAKUYU-AŞIROĞLU OBRUĞU-III}

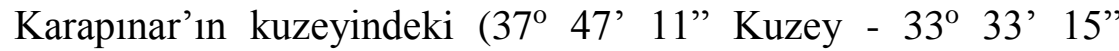
Doğu), Küçükkarakuyu Yaylası'nda yer alır. Deniz seviyesine göre üst yüzey yüksekliği $1007 \mathrm{~m}$, derinliği $8 \mathrm{~m}$, ortalama çap1 $16 \mathrm{~m}$, çevresi ise $35 \mathrm{~m}$ dir (Fotoğraf 21). Daire şeklindeki obruğun kuzeybatı yamaçlarında, derin çatlaklar vardır. Obruk tabanında, içbükey yamaçlardan gelen moloz yığınları bulunmaktadır.

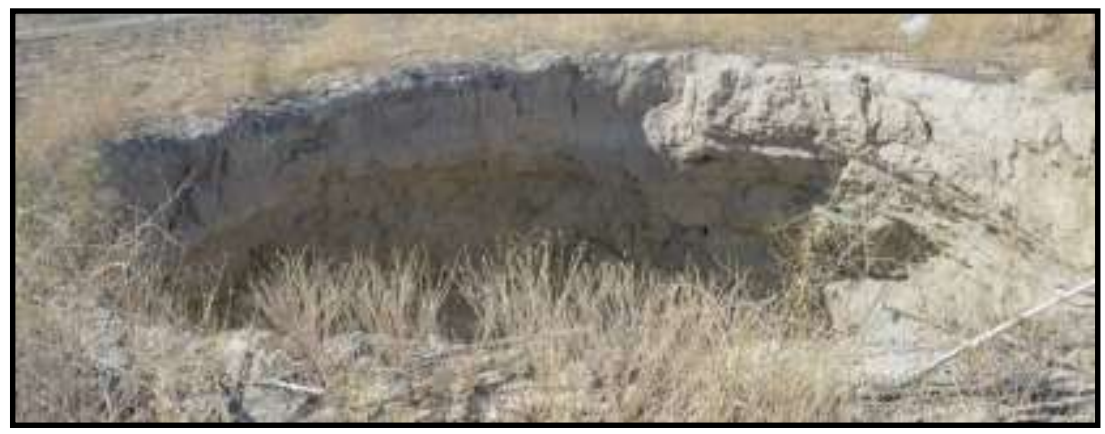

Fotoğraf 21: Küçükkarakuyu Yaylast-Aşıroğlu Obruğu III

\subsection{KÖKEN OBRUĞU-I}

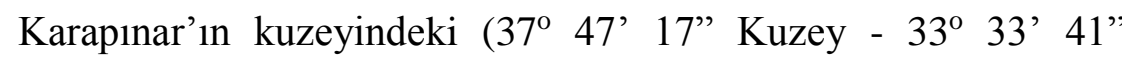
Doğu), Köken Yaylası'nda Ahmet Köken'e ait arazide yer alır. Obruk, 2011 yılında gölsel depolar içerisinde Yaşça Fayı'na bağlı olarak oluşmuştur. Deniz seviyesine göre üst yüzey yüksekliği $1005 \mathrm{~m}$, derinliği $1 \mathrm{~m}$, ortalama çap $10 \mathrm{~m}$, çevresi ise $40 \mathrm{~m}$ dir. Daire şeklindeki obruğun tabanında, kademeli olarak çöktüğünü gösteren iç içe girmiş tabakalar yer alır (Fotoğraf 22).

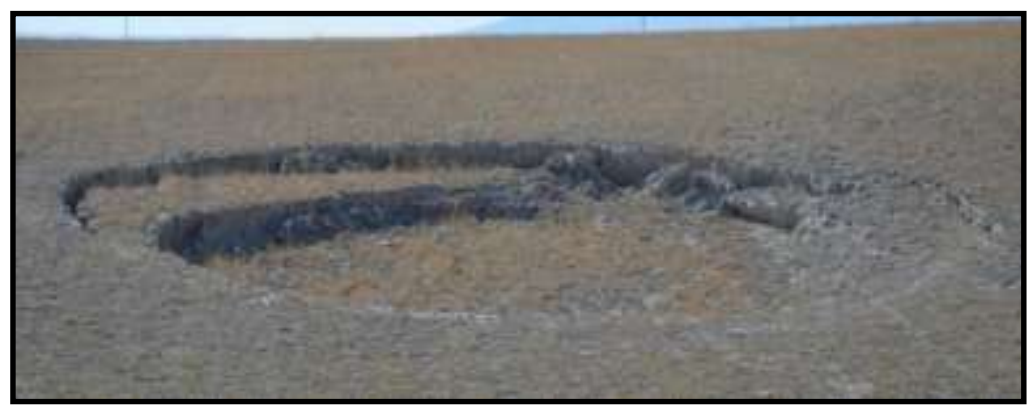

Fotoğraf 22: Köken Obruğu-I 


\subsection{KÖKEN OBRUĞU-II}

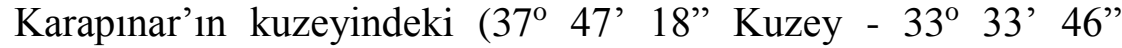
Doğu), Köken Yaylası'nın güneyinde yine Ahmet Köken'e ait tarlada yer almaktadır. 2011 yılında oluşan obruğun deniz seviyesine göre üst yüzey yüksekliği $1012 \mathrm{~m}$, derinliği $1 \mathrm{~m}$, ortalama çap1 $16 \mathrm{~m}$, çevresi ise $50 \mathrm{~m}$ dir (Fotoğraf 23).

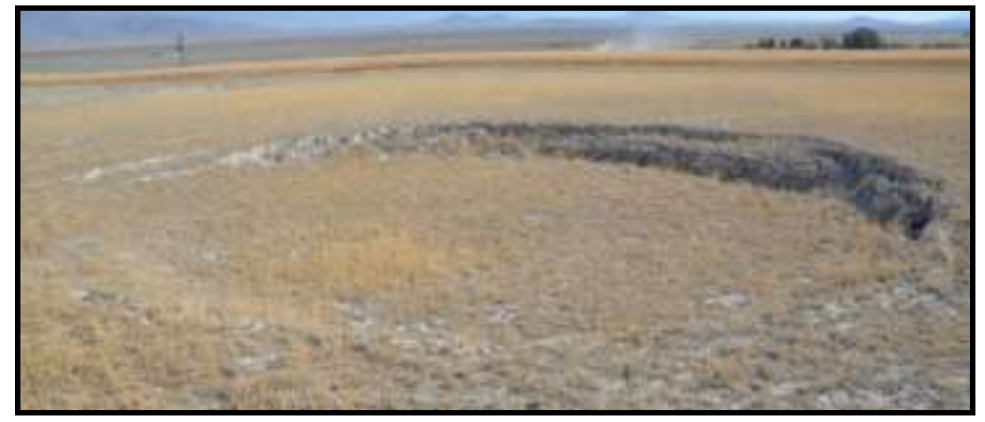

Fotoğraf 23: Köken Obruğu-II

\subsection{KÖKEN OBRUĞU-III}

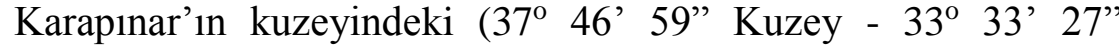
Doğu), Köken Yaylası'nda Osman Şenses'e ait tarlada yer almaktadır. 2013 Eylül ayı içinde oluşan obruğun deniz seviyesine göre üst yüzey yüksekliği $1006 \mathrm{~m}$, derinliği $0.5 \mathrm{~m}$, ortalama çapı $18 \mathrm{~m}$, çevresi ise $55 \mathrm{~m}$ dir. Daire şeklindeki obruğun kenarlarında çatlaklar bulunmaktadır (Fotoğraf 24).

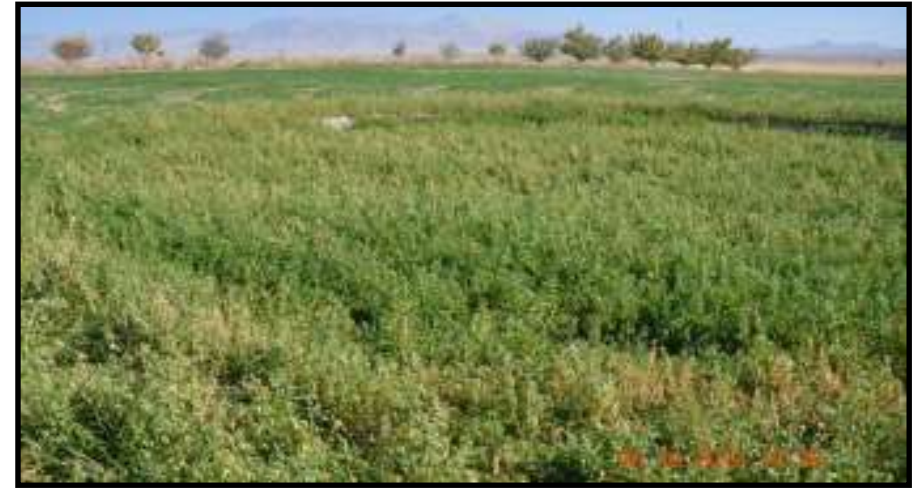

Fotoğraf 24: Köken Obruğu-III 


\subsection{SEYITHACI YAYLASI OBRUKLARI}

Karapınar'a 11 km uzaklıktaki Seyithacı Yaylası'nda 2007 ve 2014 yılları arasında 10 obruk oluşmuştur. Bunların dişında Mayıs 2013 yılında yaylanın güneyindeki meskenler arasındaki tarlada, yeni oluşmaya başlamış bir çöküntü alanı bulunmaktadır. Bu çöküntü, $37^{\circ} 48^{\prime}$ 37' kuzey - 33 34' 41" doğu koordinatlarındadır. Deniz seviyesine göre üst yüzey yükseltisi $1012 \mathrm{~m}$ ve çap $5 \mathrm{~m}$ dir. $\mathrm{Bu}$ da gösteriyor ki bu sahada yeni obruklar oluşabilecektir.

\subsection{SEYITHACI OBRUĞU-I}

Karapınar'in kuzeyindeki ( $37^{\circ} 48^{\prime} 55^{\prime \prime}$ Kuzey - 33 34' 51" Doğu) Seyithacı Yaylası'nda yer alır. Obruk, 2007 yılında gölsel depolar içerisinde oluşmuştur. Deniz seviyesine göre üst yüzey yüksekliği 1011 $\mathrm{m}$, derinliği ise $1 \mathrm{~m}$ dir. Kabaca elips şeklindeki obruğun çevresi $47 \mathrm{~m}$, uzun ekseni 15 m kısa ekseni 12 m olarak ölçülmüştür. Obruk kenarında, çatlak sistemlerine bağlı olarak blok göçmeler olmuştur (Fotoğraf 25).

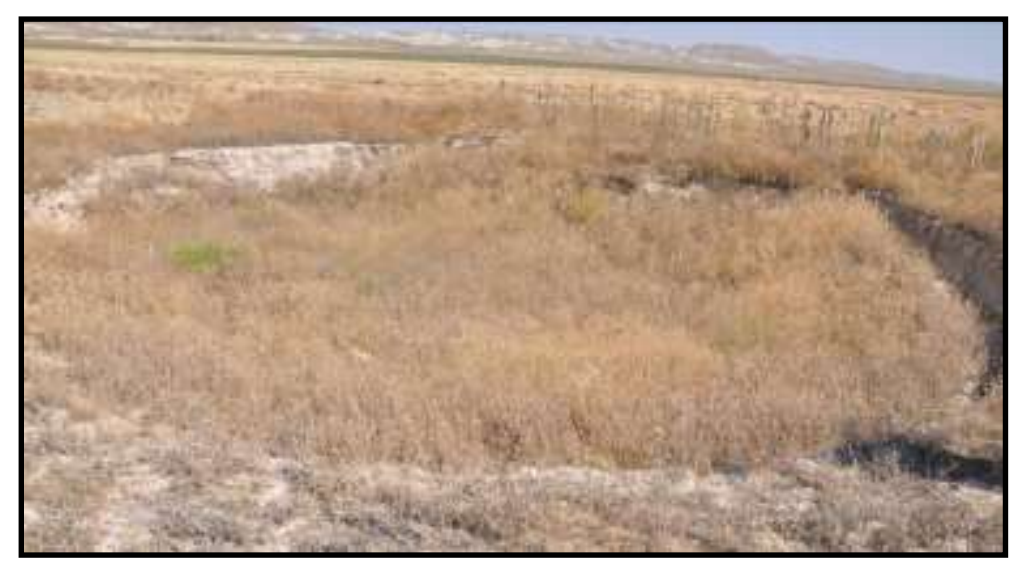

Fotoğraf 25: Seyithacı Obruğu-I

\subsection{SEYITTHACI OBRUĞU-II}

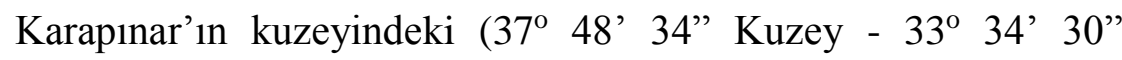
Doğu), Seyithacı Yaylası'nın güneybatısında yer alır. Obruk, 2007 yılı Haziran ayında alüvyon örtü içerisinde stabilize bir yolun tam üzerinde oluşmuştur. Deniz seviyesine göre üst yüzey yüksekliği $1010 \mathrm{~m}$, derinliği ise $3 \mathrm{~m}$ dir. Elips şeklindeki obruğun uzun ekseni $16 \mathrm{~m}$, kısa ekseni $13 \mathrm{~m}$ 
ölçülmüştür. Obruk kenarında, kayma ve çökmelerle oluşmuş moloz yı ğınları yer alır (Fotoğraf 26).

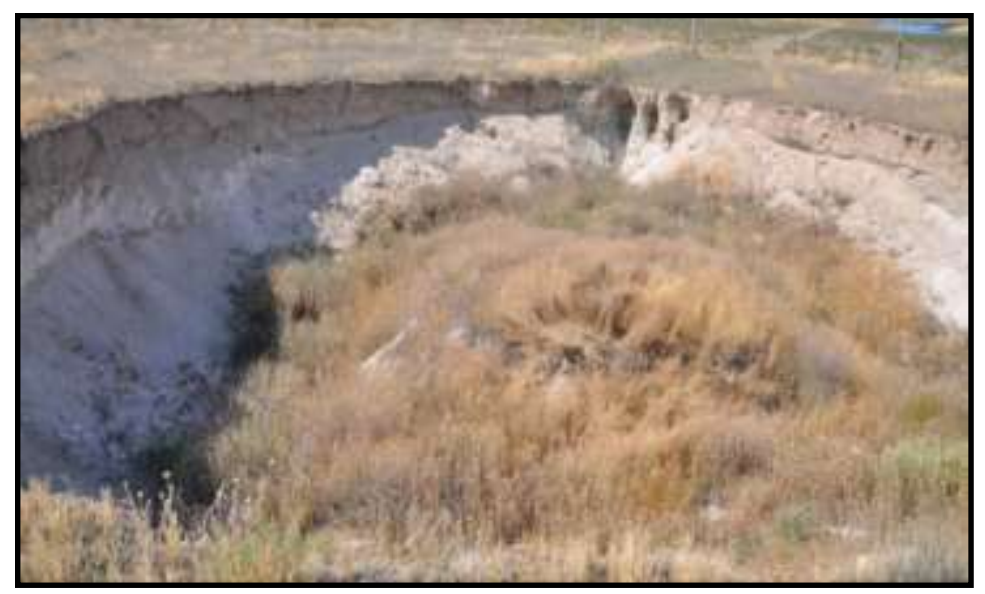

Fotoğraf 26: Seyithacı Obruğu-II

\subsection{SEYITHACI OBRUĞU-III}

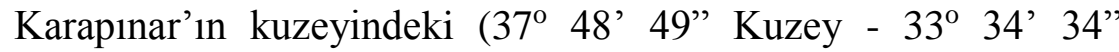
Doğu), Seyithacı Yaylası'nın kuzeydoğusunda yer alır. Obruk, 2007 y1lı Temmuz ayında oluşmuştur. Deniz seviyesine göre üst yüzey yüksekliği $1011 \mathrm{~m}$, derinliği ise $4 \mathrm{~m}$ dir. Kabaca elips şeklindeki obruğun uzun ekseni 25 m, kısa ekseni 22 m olarak ölçülmüştür (Fotoğraf 27). Obruğun doğu ve batı kesimlerinde, derin çatlak sistemleri gelişmiştir. Kuzeybatıdaki çatlaklar, $4 \mathrm{~m}$ derinliğe ulaşmaktadır. Obruk kenarında, çatlak sistemlerine bağlı olarak blok göçmeler olmuştur.

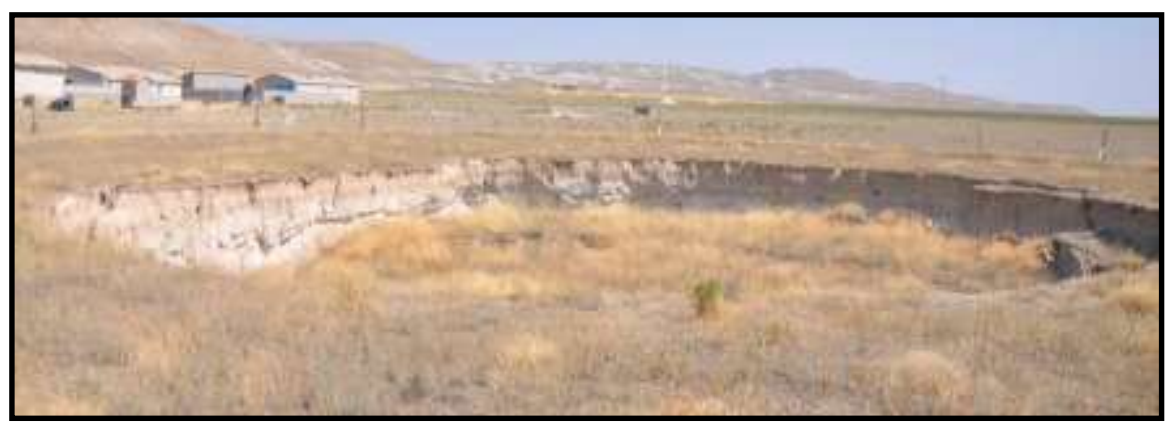

Fotoğraf 27: Seyithacı Obruğu-III 


\subsection{SEYITTHACI OBRUĞU-IV}

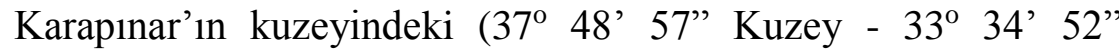
Doğu), Seyithacı Yaylası'nın kuzeydoğusunda yer alır. 2008 yılı Temmuz ayında oluşan obruğun deniz seviyesine göre yüksekliği 1009 $\mathrm{m}$, derinliği ise $2 \mathrm{~m}$ dir. Elips şeklindeki obruğun çevresi $58 \mathrm{~m}$, uzun ekseni 17 m, kısa ekseni ise 15 m olarak ölçülmüştür (Fotoğraf 28).

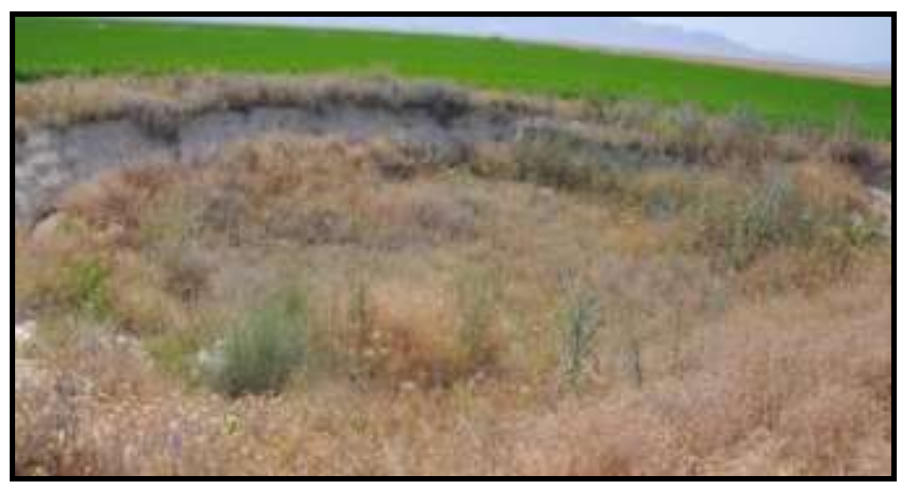

Fotoğraf 28: Seyithacl Obruğu-IV

\subsection{SEYITTHACI OBRUĞU-V}

Karapınar'ın kuzeyindeki ( $37^{\circ} 48^{\prime}$ 54" Kuzey - 33' 34' 52" Doğu), Seyithacı Yaylası'nda yer alır. 2008 yılı Ekim ayında oluşan obruğun deniz seviyesine göre yüksekliği $1009 \mathrm{~m}$, derinliği ise $4 \mathrm{~m}$ dir. Obruğun çevresi $41 \mathrm{~m}$, uzun ekseni $14 \mathrm{~m}$, kısa ekseni ise $12 \mathrm{~m}$ olarak ölçülmüştür. Obruk kenarında çatlaklara bağlı olarak blok göçmeler olmuştur (Fotoğraf 29).

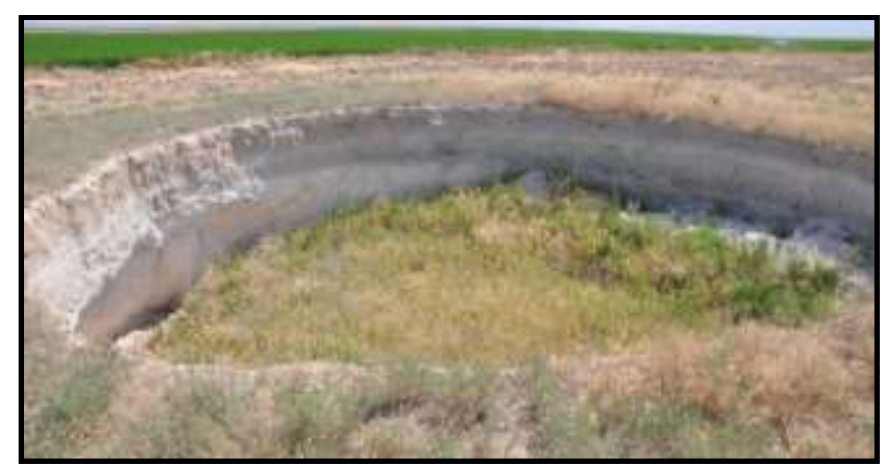

Fotoğraf 29: Seyithacı Obruğu-V 


\subsection{SEYİTHACI OBRUĞU-VI}

Karapınar'1n kuzeyindeki $\left(37^{\circ} 48^{\prime} 18^{\prime \prime}\right.$ Kuzey - $33^{\circ} 34^{\prime} 26^{\prime \prime}$ Doğu), Seyithacı Yaylası'nın güneyinde yer alır. 2008 yılında marn ve killi formasyonlar içerisinde oluşmuştur. Deniz seviyesine göre üst yüzey yüksekliği $1012 \mathrm{~m}$, derinliği ise $6 \mathrm{~m}$ dir. Daire şeklindeki obruğun çevresi $30 \mathrm{~m}$, ortalama çap1 $6 \mathrm{~m}$ olarak ölçülmüştür. Obruk kenarında, obruğun genişlediğini gösteren çatlaklar vardır (Fotoğraf 30).

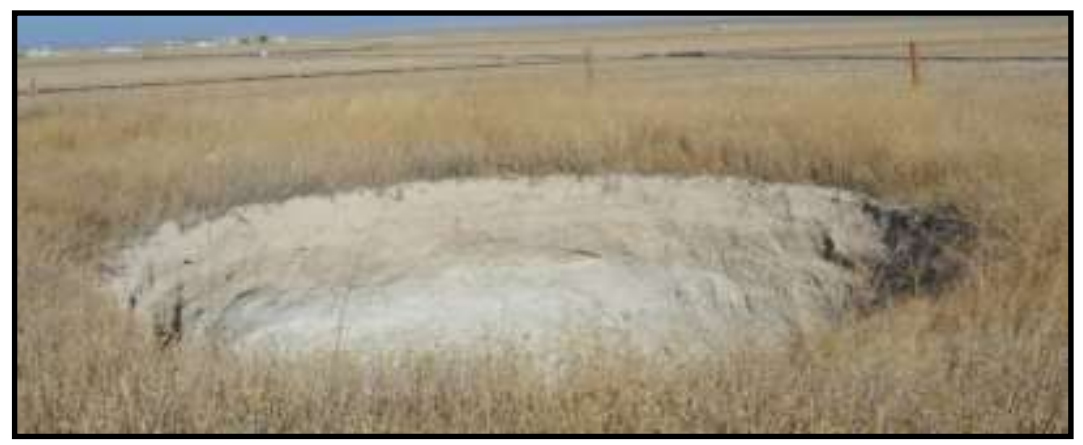

Fotoğraf 30: Seyithacl Obruğu-VI

\subsection{SEYITTHACI OBRUĞU-VII (HÜSEYİN İVRIZ)}

Karapınar'1n kuzeyindeki (37 48'09" Kuzey - 33 34'00” Doğu) Seyithacı Yaylası'nın güneybatısında yer alır. Obruk, Çiftçi Hüseyin İvriz'e ait arazide Nisan 2009'da oluşmuştur. Deniz seviyesine göre üst yüzey yüksekliği $1034 \mathrm{~m}$, derinliği ise $5 \mathrm{~m}$ dir. Kabaca daire şeklindeki obruğun çevresi $78 \mathrm{~m}$, ortalama çapı ise $13 \mathrm{~m}$ olarak ölçülmüştür. Obruk kenarında, obruğun genişlemesini gösteren çatlaklar vardır (Fotoğraf 31).

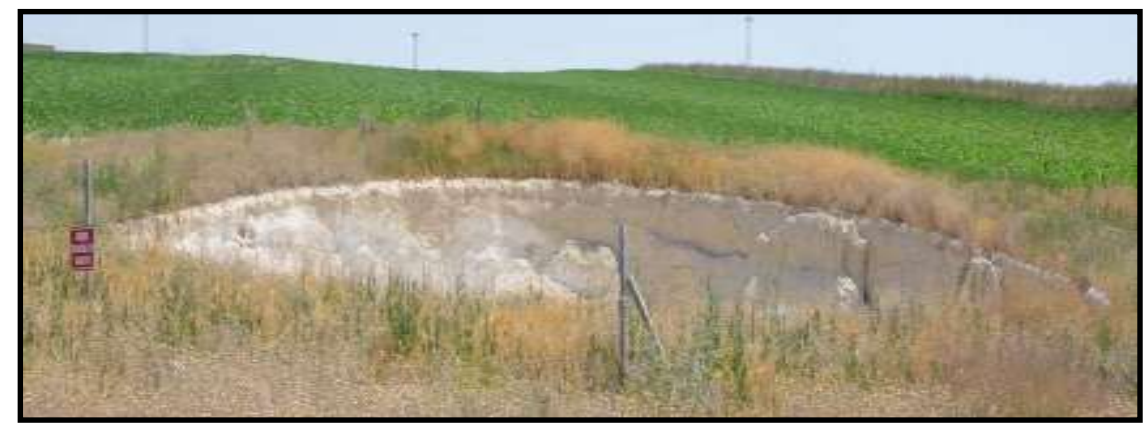

Fotoğraf 31: Seyithacı Obruğu-VII 


\subsection{SEYITTHACI YAYLASI OBRUĞU-VIII}

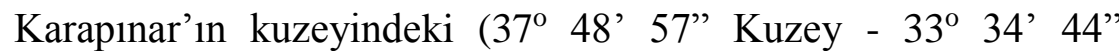
Doğu), Seyithacı Yaylası'nın kuzeydoğusunda yer alır. 2009 yılında oluşan obruğun deniz seviyesine göre üst yüzey yüksekliği $1010 \mathrm{~m}$ dir. Tarlayı işleyen vatandaşın ifadesine göre; obruğun doldurulmadan önceki derinliği $2 \mathrm{~m}$, çap $3 \mathrm{~m}$, çevresinin ise $12 \mathrm{~m}$ olduğu belirlenmiştir.

\subsection{SEYİTHACI OBRUĞU-IX}

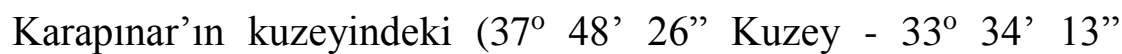
Doğu), Seyithacı Yaylası'nın güneyinde yer alır. 2012 yılında oluşan obruğun deniz seviyesine göre üst yüzey yüksekliği $1016 \mathrm{~m}$, derinliği 0.5 $\mathrm{m}$ dir. Kabaca daire şeklindeki obruğun ortalama çapi $16 \mathrm{~m}$, çevresi $80 \mathrm{~m}$ olarak ölçülmüştür. Obruğun kuzey yamaçlarında diklikler belirgindir.

\subsection{SEYITHACI OBRUĞU-X}

Karapınar'ın kuzeyindeki Seyithacı Yaylası'nda Temmuz 2014'te yayla yolunun üzerinde $30 \mathrm{~m}$ çapında ve $1.5 \mathrm{~m}$ derinliğinde bir obruk meydana gelmiştir. Obruğun oluşumu sırasında can kaybı olmamıştır. Ancak bir otomobil ve ev zarar görmüştür (Fotoğraf 32).

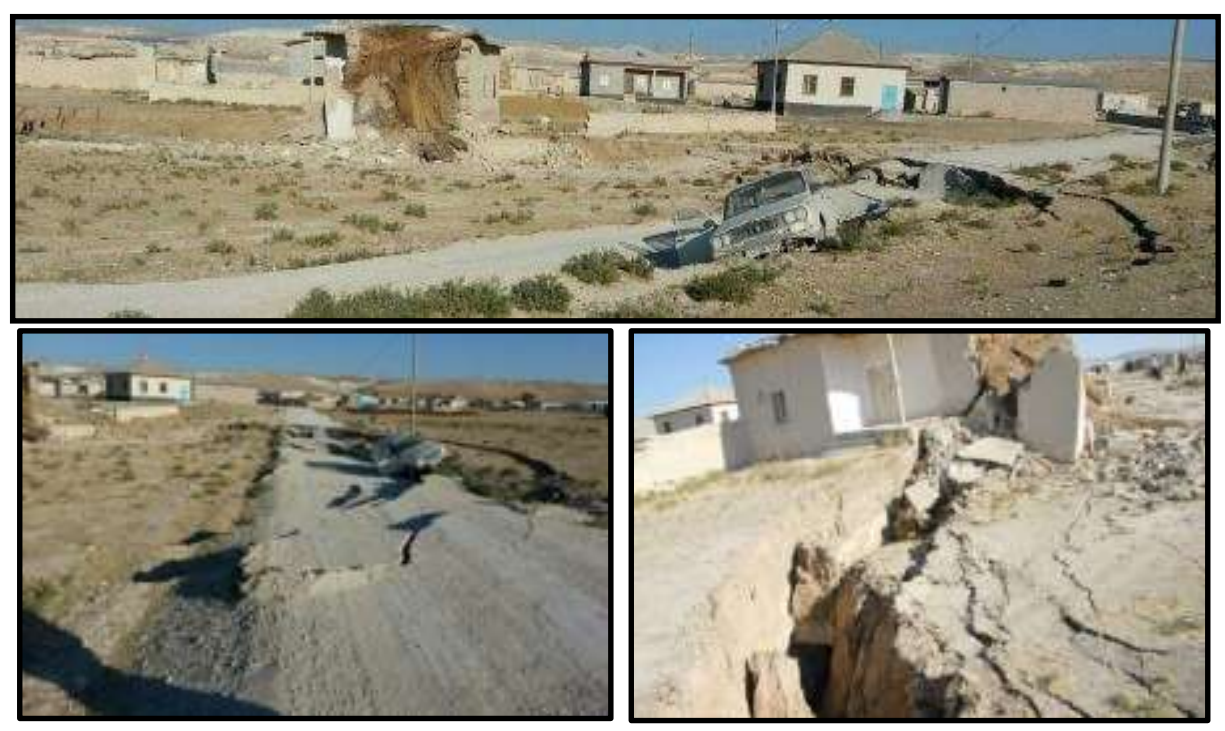

Fotoğraf 32: Temmuz 2014'te oluşan Seyithacı Obruğu-X 


\subsection{8.İÇERİÇUMRA ABAZ OBRUĞU}

İçeriçumra Beldesi'nin $14 \mathrm{~km}$ batısında $\left(37^{\circ} 33^{\prime} 53^{\prime \prime}\right.$ Kuzey - $32^{\circ}$ 38' 32" Doğu) sondaj kuyuları mevkiinde (Abaz Yolu) yer alır. Obruk, Kuaterner yaşlı alüvyon tabakalar içersinde oluşmuştur. Deniz seviyesine göre üst yüzey yüksekliği $1027 \mathrm{~m}$, derinliği $8 \mathrm{~m}$ dir. Kabaca daire şeklindeki obruğun çap1 $10 \mathrm{~m}$ olarak ölçülmüştür. 2012 yılı Temmuz ayında oluşan obruk, hafriyat malzemesi ile doldurulmuştur (Fotoğraf $33)$.

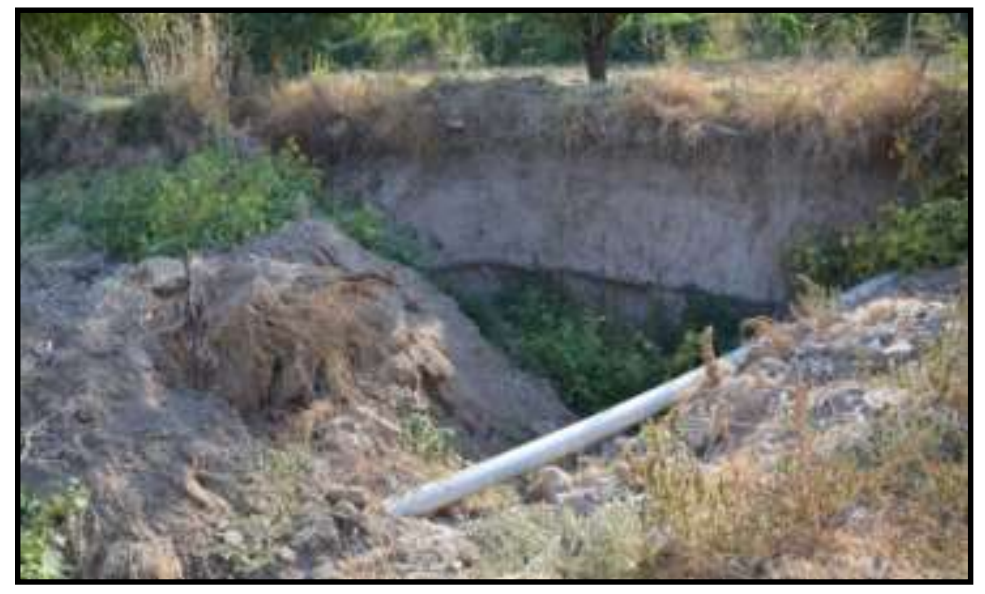

Fotoğraf 33: Doldurulan İçeriçumra Abaz Obruğu

\subsection{IÇERIÇUMRA ÇAKILLAR OBRUKLARI}

İçeriçumra Çakıllar Mevkii'nde farklı tarihlerde 3 tane obruk oluşmuştur. Bunlardan birincisi 2005, ikincisi 2008 ve üçüncüsü de 2009 yılında meydana gelmiştir. Bu obrukların her üçü de tarla sahipleri tarafından doldurulmuştur.

Bunlardan ilk obruk, 2005 yılının Ekim ayında İçeriçumra Çakıllar Mevkii'nde oluşmuştur. 2006 yılında yaptığımız ölçümlerde daire şekilli obruğun çap1 $5 \mathrm{~m}$, derinliği $9 \mathrm{~m}$ olarak ölçülmüştür. $\mathrm{Bu}$ dönemde obruğun yamaçlarında kireçtaşı, kil ve marnlı tabakalar belirgin bir şekilde görülmekteydi (Fotoğraf 34). Ancak 2013 yılı Ekim ayında bu obruğun tamamen doldurulduğu gözlenmiştir. 


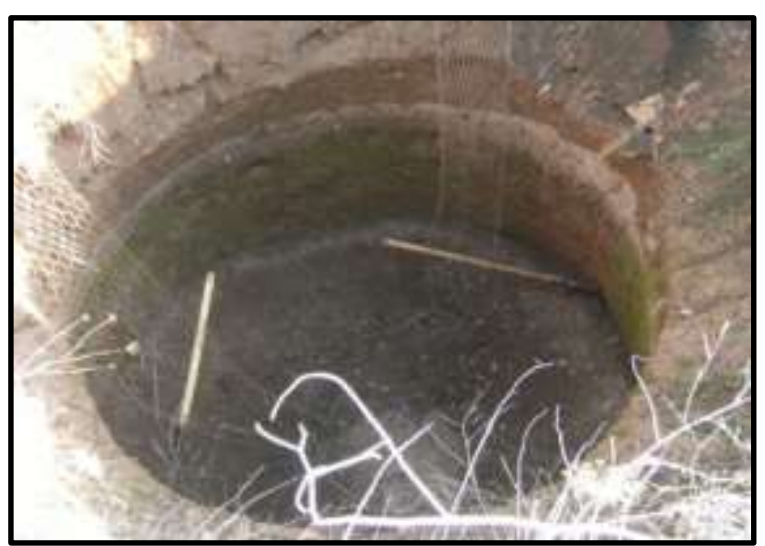

Fotoğraf 34: Doldurulmuş olan Çakillar Obruğu-I (fotoğraf 2008'e ait)

Diğer iki obruk, İçeriçumra - Seçme karayolunun 8. Km sinin güneyinde aynı tarlada meydana gelmiştir. Obruklarla ilgili bilgi için tarlayı eken Hasan Görmez'in gösterdiği yerde ( $37^{\circ} 34^{\prime} 45^{\prime}$ ' Kuzey - $32^{\circ}$ 35' 45" Doğu) inceleme yapılmıştır. Görmez, 2008 yılında oluşan obruğun $4 \mathrm{~m}$ çapında ve $7 \mathrm{~m}$ derinliğinde, 2009 yılında oluşanın da $2 \mathrm{~m}$ çapında ve $4 \mathrm{~m}$ derinliğinde olduğunu ifade etmiştir. Belli bir süre sonrada tarlayı işleyebilmek için obrukları kapattıklarını belirtmiştir. Ancak kapatılan obrukların birinde tekrar küçükte olsa çökme ve çatlak izleri görülebilmektedir.

\subsection{MAY OBRUĞU-I (BÜYÜK)}

Konya kent merkezinin 23.4 km güneyindeki (37 31' 19" Kuzey $-33^{\circ} 32^{\prime} 23^{\prime}$ Doğu), May Barajı'nın kuzeybatısında yer alır. Obruk, alüvyon örtü içerisinde 2002 yılı Şubat ayında oluşmuştur. Deniz seviyesine göre üst yüzey yüksekliği $1056 \mathrm{~m}$, derinliği $10 \mathrm{~m}$ dir. Daire şeklindeki obruğun ortalama çap1 $70 \mathrm{~m}$, çevresi de yaklaşık $230 \mathrm{~m}$ ölçülmüştür. Obruk yamaçlarında çatlaklar mevcuttur. Güneybatı ve güneydoğu yönünden gelen dereler, buradaki yamaçları parçalamıştır. İlk oluştuğunda obrukta su bulunurken daha sonra May Barajı'nın suyunun azalmasına bağlı olarak obruğun suyu çekilmiştir. 2004 yılı Ocak ayında May obruklarında yaptığımız incelemede tespit edilen; obruğun batı kenarında 2.5-3 m'ye varan dairesel çatlaklı kesimin bugün (Eylül 2013) büyük ölçüde çöktüğü anlaşılmıştır. Obruk tabanı, kuzey-güney yönünde $48 \mathrm{~m}$ dir. Tabanında, çatlaklı killi topraklar dikkati çeker (Fotoğraf 35). 


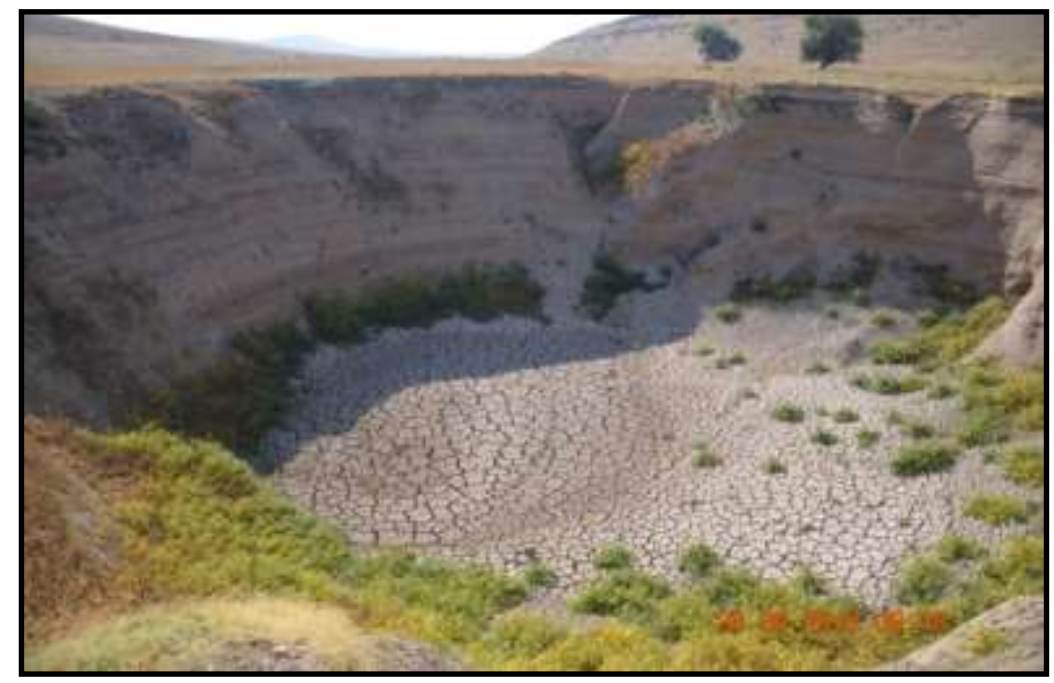

Fotoğraf 35: May Obruğu-I (Büyük)

\subsection{MAY OBRUĞU-II (ORTANCA)}

Konya kent merkezinin 23.4 km güneyindeki ( $37^{\circ} 31^{\prime}$ '17' Kuzey $-33^{\circ} 32^{\prime}$ 25” Doğu), May Barajı'nın kuzeybatısında May Obruğu-I'in 35 $\mathrm{m}$ güneydoğusunda yer alır (Fotoğraf 36). Obruk, alüvyon örtü içerisinde 2002 yılı Şubat ayında oluşmuştur. Deniz seviyesine göre üst yüzey yüksekliği $1055 \mathrm{~m}$, derinliği $5 \mathrm{~m}$ dir. Daire şeklindeki obruğun ortalama çapı $22 \mathrm{~m}$, çevresi ise $95 \mathrm{~m}$ olarak ölçülmüştür. Obruk yamaçlarında, çatlak sistemlerine bağlı olarak göçme ve kaymalar devam etmektedir. Obruk tabanı, kayma ve göçme enkazı ile dolgulanmıştır. Yağışı mevsimlerde çevreden gelen suların tabanda biriktiği ve bu suların tabanda bulunan iki düden tarafından tahliye edildiği tespit edilmiştir.

\subsection{MAY OBRUĞU-III (KÜÇÜK)}

May Obruğu-II (Ortanca)'nin $40 \mathrm{~m}$ güneyinde yer alır (Fotoğraf 37). Obruk, 2002 yılı Şubat ayında alüvyon örtü formasyonları içerisinde oluşmuştur. Deniz seviyesine göre üst yüzey yüksekliği $1054 \mathrm{~m}$, derinliği $3 \mathrm{~m}$ dir. Kabaca daire şeklindeki obruğun ortalama çap $11 \mathrm{~m}$, çevresi ise $60 \mathrm{~m}$ olarak ölçülmüştür. Obruk yamaçları disimetriktir. Güneydoğu yamacı ise bu yönden gelen derenin açtığı çukurluk ile alçalmıştır. Tabanda killi topraklar dikkati çekmektedir. Yağışlı mevsimlerde çevreden gelen suların tabanda biriktiği görülür. 


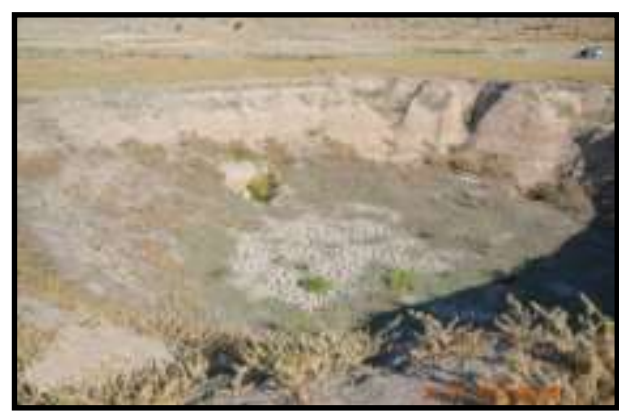

Fotoğraf 36: May Obruğu-II (Orta)

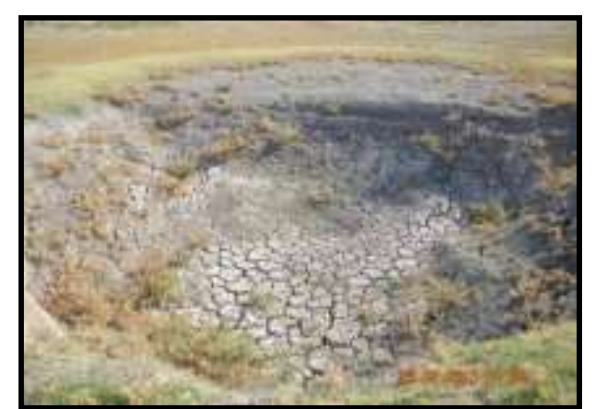

Fotoğraf 37: May Obruğu-III (Küçük.)

\subsection{KADINHANI HANÇERLİ OBRUĞU}

Kadınhanı ilçe merkezine $26 \mathrm{~km}$ uzaklıktaki Pusat Köyü'nün kuzey batısında (38 24' 16" Kuzey - 32 $11^{\circ}$ '52” Doğu) 2013 yılı Ekim ayında meydana gelmiştir. Obruk, Üst Miosen - Pliosen yaşlı gölsel örtü formasyonu içerisinde oluşmuştur. Obruğun deniz seviyesine göre üst yüzey yüksekliği $1004 \mathrm{~m}$, uzun ekseni çap1 $18 \mathrm{~m}$, derinliği de $7 \mathrm{~m}$ dir. Obruğun kuzey ve doğu yamacında diklik daha fazladır. Batı yamacında blok göçmeler ve derin çatlaklar, güney yamacında ise moloz yığını yer almakta idi (Fotoğraf 38).

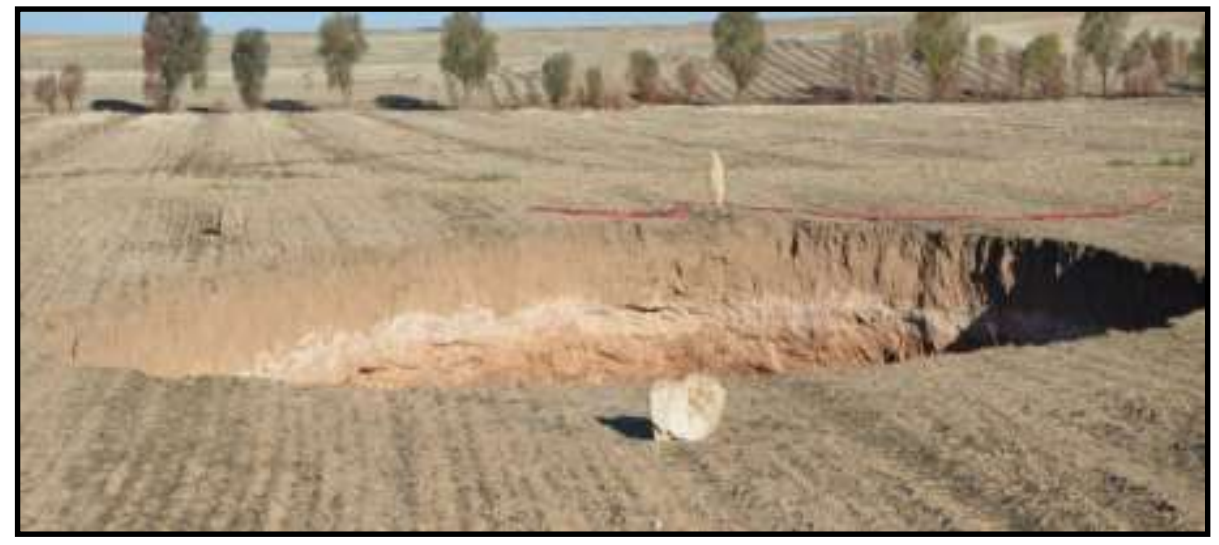

Fotoğraf 38: Kadınhanı Hançerli Obruğu

Obruk oluştuktan 4 ay sonra tarla sahibi tarafından hafriyatla doldurulmuştur. Obruk doldurulduktan 2 ay sonra yapılan incelemede obruğun yaklaşık $1 \mathrm{~m}$ çöktüğü ve obruk kenarlarında çatlakların oluştuğu görülmüş̧tür (Fotoğraf 39). 


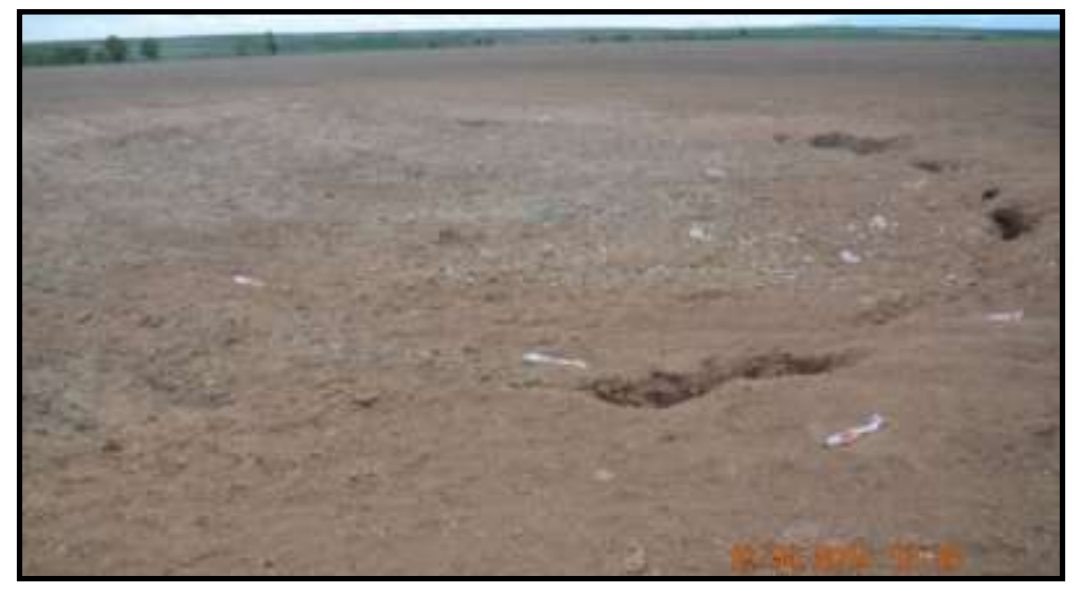

Fotoğraf 39: Kadınhanı Hançerli Obruğu’nun kapatılmış görüntüsü

\section{SONUC}

Konya İli'nde 61'i eski, 43'ü yeni oluşumlu olmak üzere 104 adet obruk tespit edilmiştir. Günümüze yakın tarihlerde oluşmuş obruklar; Karapınar ilçesinin Seyithacı, Büyükkarakuyu, Küçükkarakuyu, Köken, Eşeli, Yavşançukuru, Akkuyu yaylaları ile İçeriçumra'nın batısında, Akören May Barajı'nın kuzeybatısında yoğunlaşmaktadır (Şekil 3).

Obruk oluşum sıklığının son yıllarda arttığı dikkat çekmektedir. $\mathrm{Bu}$ sıklığın artmasında insanların yeraltı suyunu aşırı kullanmasının etkili olduğu kanaatindeyiz. Son 30 y1llık periyotta yeraltı su seviyesindeki hızlı düşüşü; Akgöl (Ereğli), Acıgöl (Karapınar), Meke Gölü (Karapınar), Timraş (Çumra), Kızören (Karatay), Çıralı (Karapınar) obruk göllerinden anlamaktayız. Konya Ovası'ndan Tuz Gölü'ne doğru olan yeraltı suyu akışı sırasında, yeraltı suları temas halinde bulunduğu karstik kayaçları çözmekte ve yeraltı boşlukları oluşmaktadır. Bu boşluklar, gerek yeraltı suları, gerekse insanların yanlış arazi kullanımı sonucunda çökmekte ve obruk adını verdiğimiz karstik oluşumlar ortaya çıkmaktadır. Günümüzdeki mevcut arazi ve yeraltı suyu kullanımı sürdürüldügü takdirde yeni obruk oluşumları da beklenmektedir.

Güncel obruklar, Karapınar, Çumra, Kadınhanı ve çevresinde yerleşim merkezleri ve tarım alanlarını etkilemektedir. Bundan dolayı yaylalar terk edilmekte ve tarım yapılamamaktadır. Obruk oluşma riski 
taşıyan yöredeki insanlar ise başta Konya il merkezi olmak üzere ilçe merkezlerine göç etmek zorunda kalmaktadır.

Güncel obrukların bir kısmı tarla sahipleri tarafından dolduruldukları tespit edilmiştir. Ancak bu doldurulmuş obruklar, üstü örtülmüş bir tuzak şekline dönüşmektedir. Bu durum gelecekte can ve mal kaybına yol açabilir. Bu olumsuzluklara rağmen Konya ili içerisinde yer alan obruklar, gerek oluşumları ve gerekse sahip oldukları özellikleri açısından ülkemizin emsalsiz güzelliklerindendir. $\mathrm{Bu}$ güzelliklerin tanıtılması, paylaşılması, korunması için bazı önlemlerin alınması gerekmektedir.

Bazı obrukların çevresinde dikenli tel ile bir koruma önlemi alınmış olsa da, bu dikenli tel direkleri çoğu yerde yıkılmış ve önemini kaybetmiştir. $\mathrm{Bu}$ nedenle kısa zamanda tehlike arz eden obrukların kenarına koruma perdeleri ve uyarı levhaları konulmalıdır. Bunlar yapılırken obruğa gelecek ziyaretçiler de düşünülerek sağlam zeminin olduğu bölüme bir kapı düzeneği yapılmalıdır.

\section{KAYNAKÇA}

Bayarı, C. Serdar, Pekkan, Emrah ve Özyurt, N. (2008). Konya Kapalı Havzası'nda Hipojenik Karstlaşma Sonucu Oluşan Obrukların Oluşum Süreçleri, Hydrogeology Journal, DOI 10.1007/s1040-008-0351-9.

Bozyiğit, Recep ve Tapur, Tahsin (2009). Konya Ovası ve Çevresinde Yeraltı Sularının Obruk Oluşumlarına Etkisi, Selçuk Üniversitesi Sosyal Bilimler Enstitüsü Dergisi, Sayı 21, s.137-155, Konya.

Canik, B. (1997). Konya Dolaylarında Suların Oluşturduğu Doğal Anitlar ve Bunların Korunması, 20.Y1l Jeoloji Sempozyumu Bildiriler, s.159-166, Konya.

Çörekçioğlu, İ. (1994). Konya Karapınar-Kızören Arasındaki Obrukların Oluşumu ile İlgili Hidrojeolojik Etüt Raporu, DSİ 4. Bölge Müdürlüğü, Konya. 
Erol, O. (1990). Konya-Karapınar Kuzeybatısındaki Obrukların Gelişimi ile Konya ve Tuz Gölü Pleistosen Plüviyal Gölleri Arasındaki İlişkiler, İstanbul Üniv. Deniz Bilimleri ve Coğrafya Enstitüsü Dergisi, Sayı 7, s.5-49, İstanbul.

Ertek, T. A. (2009). Obruk Platosu'nda Devam Eden Obruk Oluşumları, TÜBİTAK Bilim ve Teknik Dergisi, Ekim 2009, Y1l 42, Say1 503, s.66-71. Ankara.

Göçmez, G. (2011). Konya İlindeki Obruklar ve Traverten Konileri, 26-27 Kasım 2011 I. Konya Kent Sempozyumu Bildiriler Kitab1, s.459-464, Konya.

Güldalı, N. ve Şaroğlu, F. (1983). Konya Yöresi Obrukları, T.J.K. Yeryuvarı ve İnsan, Cilt 7, Sayı 4, Ankara.

Lahn, E. (1940). Konya Mıntıkasındaki Karst Hadiseleri ve Bunların Ziraat Bakımından Ehemmiyeti, MTA Enstitüsü Mecmuas1, Say1 4/21, s.620-626, İstanbul.

Selçuk Biricik, A. (1992). Obruk Platosu ve Çevresinin Jeomorfolojisi, Marmara Üniv. Yayın No 531, İstanbul.

Törk, Koray (Proje Başkan1); Erduran, Barboros; Güner, İ. Noyan; Ateş, Şerafettin; Avcı, Kerem; Çınar, Aslan; Keleş, Sinan; Ayva, Aytekin; Demirbaş, Şevket, Yılmaz, N. Pınar ve Sülükçü, Selma (2010). Konya Havzası'nda Karstik Çöküntü Alanlarının Belirlenmesi ve Tehlike Değerlendirilmesi Projesi 2009 Ylı Ara Rapor (MTA Proje No: 2009.14.03.2), MTA Genel Müdürlügü, Jeoloji Etütleri Dairesi, Ocak 2010, Ankara.

Üstün, A. Tuşa, E. A. ve Ramazan A. (2007). Konya Kapalı Havzasında Yeraltı Suyu Çekilmesi ve Olası Sonuçlarının Jeodezik Yöntemlerle İzlenmesi, 3. Mühendislik Ölçmeleri Sempozyumu, 24 -26 Ekim 2007, s.52-61, Konya. 